\title{
Physical activity motives, barriers, and preferences in people with obesity: a systematic review
}

Aurélie Baillot ${ }^{1,2,3}$, Stéphanie Chenail ${ }^{2}$, Naiara Barros Polita ${ }^{4}$, Mylène Simoneau ${ }^{5}$, Mathilde Libourel ${ }^{6,7}$, Evy Nazon ${ }^{1}$, Eléonor Riesco ${ }^{6}$, Dale S. Bond ${ }^{7}$, Ahmed J. Romain ${ }^{9,10}$

${ }^{1}$ Department of nursing. University of Québec en Outaouais, Gatineau, QC, Canada

${ }^{2}$ Institut du savoir Montfort-Recherche, Ottawa, ON, Canada

${ }^{3}$ Centre de recherche du Centre Intégré de Santé et Services Sociaux de l'Outaouais, Gatineau, QC, Canada

${ }^{4}$ Department of nursing. State University of Northern Paraná, Bandeirantes, PR, Brazil

${ }^{5}$ School of Human Kinetics, Faculty of Health sciences, University of Ottawa, Ottawa, ON, Canada

${ }^{6}$ Faculty of physical activity sciences, University of Sherbrooke and Research Center on Aging, CIUSSS de l'Estrie - CHUS, Sherbrooke, QC, Canada

${ }^{7}$ Institut des Sciences et Industries du vivant et de 1'environnement, AgroParisTech, Paris, France

${ }^{8}$ Department of Psychiatry and Human Behavior, Weight Control and Diabetes Research Center, The Miriam Hospital/Brown Alpert Medical School, Providence, RI, USA. 
Preprint version

${ }^{9}$ School of kinesiology and physical activity sciences. Faculty of Medicine. Université de Montréal, QC, Canada

${ }^{10}$ Centre de Recherche de l'Institut Universitaire en Santé Mentale de Montréal, QC, Canada

Corresponding author: https://orcid.org/0000-0003-4874-0481

Aurélie Baillot, Université du Québec en Outaouais, 283 Boul. Alexandre-Taché, Gatineau, QC J8X 3X7 (Canada).

Office: 00 1- 819-595-3900 (1995); aurelie.baillot@uqo.ca

Keywords: Obesity, exercise, motivation, obstacles, preferences

Short title: Motives, barriers and preferences to physical activity in people with obesity

All authors are aware of and have agreed to submission to SportRxiv.

Preferred citation: Baillot, A., Chenail, S., Polita, N. B., Simoneau, M., Libourel, M., Nazon, E., Riesco, E., Bond, D., Romain, A. J. (2021). Motives, barriers and preferences to physical activity in people with obesity: a systematic review. Retrieved from osf.io/preprints/sportrxiv/rvaw3. DOI: 


\begin{abstract}
Background. Although the benefits of physical activity (PA) are well known, physical inactivity is high in people with obesity. The objective of this systematic review was to i) appraise knowledge on PA motives, barriers, and preferences in individuals with obesity, and ii) quantify the most frequently reported PA motives, barriers and preferences in this population.
\end{abstract}

Methods. Six databases (Pubmed, CINAHL, Psyarticle, SportDiscus, Web of science and Proquest) were searched until June 2020 by independent reviewers to identify relevant quantitative or qualitative articles reporting PA motives, barriers or preferences in adults with body mass index $\geq 30 \mathrm{~kg} / \mathrm{m}^{2}$. Risk of bias for each study was assessed by two independent reviewers with the Mixed Methods Appraisal Tool (MMAT).

Results. From 5,898 papers identified, 13 quantitative, 10 qualitative and 3 mixed studies were included $(\mathrm{k}=26)$. About $31 \%$ of studies have a MMAT score below $50 \%(\mathrm{k}=8)$. The three most reported PA motives in people with obesity were weight management, followed by energy/physical fitness and social support. The three most common PA barriers were lack of self-discipline/motivation, pain or physical discomfort, and lack of time. Based on the only 4 studies available, walking seems to be the preferred mode of PA in people with obesity.

Conclusions. Weight management, lack of motivation and pain are keys PA motives and barriers in people with obesity, and should be addressed in future interventions to facilitate PA initiation and maintenance. Further research is needed to investigate the PA preferences of people with obesity. 
Preprint version

\section{Introduction}

Obesity is a major public health issue in North America affecting more than $25 \%$ of adults in Canada, and $40 \%$ of adults in the United States $(1,2)$. Obesity contributes to impaired physical and mental health-related quality of life, and increased morbidity and mortality $(3,4)$. Physical activity (PA) is a cornerstone of interdisciplinary obesity treatment $(5,6)$. Indeed, the benefits of regular PA on weight management, body composition, physical fitness, and cardiometabolic health in people with obesity are well documented (7-10). However, more than half of Canadians and Americans living with obesity report to be insufficiently active $(11,12)$. Furthermore, adherence to structured PA interventions is poor and drop-out rates range from $20 \%$ to $80 \%$ (13).

In the context of PA intervention, a mismatch between patients' preferences or motives, and the PA intervention planned could adversely impact level of PA engagement (14). Integrating preferences into interventions has been considered as a patient-oriented strategy to improve participation and adherence as patients feel considered in their decisions (1417). Moreover, from a PA perspective, previous research highlights that when people with obesity were offered to self-select their PA intensity, they accumulated more PA over time $(18,19)$. Along with PA preferences among individuals with obesity, it is important to understand PA motives and barriers to inform clinicians, and health stakeholders on the development of strategies to better improve PA behavior in this population (20-23).

Past systematic reviews on motives, barriers and preferences to PA have been performed in various clinical populations (e.g., type 2 diabetes) (24-27). Although several qualitative and quantitative studies are available on this topic in people with obesity, to our knowledge, none have systematically summarized this information. Only one systematic review of qualitative studies has been carried out on PA motives and barriers in people with severe 
obesity (28), and reported that weight loss was the main reason for exercising, followed by other motives, such as the risk of diseases, and skills improvement. Physical (e.g., health problems, weight, and, pain), and psychosocial barriers (e.g., embarrassment, self-blame, lack of safety, and time) were also reported in this study (28).

Therefore, the objectives of the present systematic review were to i) appraise current qualitative and quantitative knowledge on PA motives, barriers and preferences in people with obesity, and ii) quantify which PA motives, barriers and preferences were more common in this population.

\section{Methods}

\section{Protocol and Registration}

The Preferred Reporting Items for Systematic Reviews and Meta-analysis (PRISMA) guidelines were used to perform this review (29). The protocol was pre-registered in PROSPERO (CRD42020141447).

\section{Eligibility Criteria}

Quantitative and qualitative studies were included in this review if they met the following inclusion criteria: i) constituted primary research published in peer-reviewed journals with full-text available in English or French; ii) focused on adults ( $\geq 18$ years old) with a body mass index $(\mathrm{BMI}) \geq 30 \mathrm{~kg} / \mathrm{m}^{2}$ (or more than $75 \%$ of the sample with $\mathrm{BMI} \geq 30 \mathrm{~kg} / \mathrm{m}^{2}$ if the study did not exclusively include people with obesity or did not perform sub analysis in people with obesity); iii) reported motives, barriers or preferences to PA.

Motives were defined as any perceived reasons to increase and maintain PA, and barriers as any challenges reported by participants reducing PA initiation and maintenance (25). 
Preferences were considered as patient-reported favourite choices concerning PA modalities, context, type, and supervision.

\section{Information Sources and Search}

A systematic search of eligible studies was conducted in six different databases (Pubmed, CINAHL, PsycArticles, SportDiscus, Web of science and Proquest). Selected experts (AB, AJR, DB) screened references from included articles and personal records.

The search was performed on July 23, 2019 without date restriction, using research equation including keywords and Medical Subject Headings (Mesh) terms developed with a university librarian. For example, the PubMed search strategy was the following: "Exercise"[Mesh] AND "Obesity"[Mesh] AND ("Motivation"[Mesh] OR "Patient Preference "[Mesh] OR "preference*"[All Fields] OR "barrier*"[All Fields] OR "facilitator*"[All Fields]) OR "obstacle*"[All Fields]) AND "humans"[MeSH Terms] AND (English[lang] OR French[lang]) AND "adult"[MeSH Terms]. The search strategy was modified for each database, considering their specificities. An updated search was performed on June 04 (2020) to retrieve any studies published since the initial search. See supplemental material S1 for detailed search strategies for each database.

\section{Study Selection}

All retrieved citations were imported into EndNote software (Version X9), and duplicate records were removed by one reviewer (ML). Two independent students' reviewers (ML and MS) paired with senior reviewers (AB and AJR) screened records against inclusion and exclusion criteria, first according to titles and abstracts, and then to the full-text papers of the selected abstracts. Disagreements were resolved by a third party (AB or AJR). If necessary, authors were contacted in case of missing or incomplete data for the study 
selection step. After reading the full-text papers of the selected abstracts, authors (AB, AJR, ER) decided by consensus to exclude studies performed in very specific population in order to better answer to our main objective (pregnant women (30-32), cancers survivors (3336), people with intellectual disabilities (37), veterans living with schizophrenia (38), and bariatric surgery patients (39-50)).

\section{Data Collection Process}

The following data were extracted by one review author (SC) using a data extraction form developed for the present review, and double-verified by two others (NBP, MS): authors; publication year; study setting; country; study design; sample size; participants' characteristics (age, sex, BMI and comorbidities); methods to assess PA motives, barriers and preferences; and results : survey/questionnaire items with the score or frequency associated for quantitative studies, and first and second constructs with adjectives reflecting the importance of the outcomes (many, several, etc.) for qualitative studies. To be extracted, the PA motives and barriers items should have been reported in the results section. Disagreements were resolved by having a fourth review author $(\mathrm{AB})$ returning to the full text(s) to check the accuracy of extracted data.

\section{Data Synthesis Process}

A thematic synthesis of the data extracted from qualitative studies was used following the steps proposed by Thomas and Harden (51). First, line-by-line coding driven by the objectives was performed by one reviewer (NBP). Then, similar codes were grouped into descriptive themes, including first and second order constructs, which were verified by a second reviewer (SC). Analytical themes were generated by the interpretation of descriptive themes and validated by two authors (SC, AB). Finally, themes were compared 
and integrated to quantitative categories. Results on PA motives and barriers extracted from qualitative and quantitative studies were classified in three main categories: physical, psychological and socio-ecological by two reviewers (SC and NBP) (25), and then reviewer authors (AB, AJR, SC, NBP) created subcategories by consensus to merge similar items and constructs.

Analyses

Regarding the statistical part, though a meta-analysis of proportion was planned to further rank each PA motives, barriers and preferences individually, this option was not found to be feasible given the small number of included studies per section and the high heterogeneity between these studies. Alternatively, based on the scale from Clifford et al. (24), we created a score of importance for each PA motive and barrier subcategory. Briefly, a score of importance ranging from 0 to 3 was assigned to each PA motive and barrier subcategory in each study (see table 1 for details). To then obtain a rank for each PA motive and barrier, a global score was calculated by summing each PA motive and barrier score across all the studies (maximal score of 33 for PA motives; 11 studies $\times 3$, and 69 for PA barriers; 23 studies $\times 3)$. Two authors $(\mathrm{AB}, \mathrm{SC})$ realized this step.

For PA preferences, a narrative synthesis was favoured given the small number of studies $(\mathrm{k}=4)$ and the high heterogeneity between studies. 
1 Table 1. Physical activity barriers and motives score of importance based on the studies of Clifford et al. (24)

\begin{tabular}{|c|c|c|c|c|}
\hline Scores & $\mathbf{0}$ & 1 & $2 *$ & 3 \\
\hline \multicolumn{5}{|l|}{ Quantitative data } \\
\hline $\begin{array}{l}\text { Percentage of participant who checked item as a } \\
\text { barrier (yes or no question) }\end{array}$ & \multirow{5}{*}{$\begin{array}{l}\text { PA barrier and } \\
\text { motive not reported } \\
\text { in the study }\end{array}$} & $0-24 \%$ & $25-49 \%$ & $50-100 \%$ \\
\hline $\begin{array}{l}\text { Percentage of participants that agreed based on a } \\
\text { Likert scale }\end{array}$ & & $0-24 \%$ & $25-49 \%$ & $50-100 \%$ \\
\hline $\begin{array}{l}\text { Percentage of participant who rated item as major } \\
\text { barrier (responses ranged between } 0.7 \text { to } 23.4 \% \text { ) }\end{array}$ & & $0-9 \%$ & $10-19 \%$ & $20-25 \%$ \\
\hline $\begin{array}{l}\text { Score: } 5 \text {-point Likert }(1=\text { strongly disagree, } 3= \\
\text { neither agree nor disagree, } 5=\text { strongly agree })\end{array}$ & & $1-2.0$ & $2.1-3.0$ & $3.1-5.0$ \\
\hline $\begin{array}{l}\text { Score. } 5 \text {-point Likert scale, }(1=\text { never, } 2=\text { rarely, } \\
3=\text { sometimes, } 4=\text { often, or } 5=\text { very often })\end{array}$ & & $1-1.9$ & $2.0-2.9$ & $3.0-5.0$ \\
\hline \multicolumn{5}{|l|}{ Qualitative data } \\
\hline Adjectives & $\begin{array}{l}\text { PA barrier and } \\
\text { motive not reported } \\
\text { in the study }\end{array}$ & \multicolumn{2}{|l|}{$\begin{array}{l}\text { A few women; } \\
\text { Some participants; } \\
\text { Several participants }\end{array}$} & $\begin{array}{l}\text { Mentioned by all members; Commonly } \\
\text { mentioned; Most mentioned; The first to } \\
\text { third most common; Substantial barrier; } \\
\text { Mentioned by many participants and as a } \\
\text { significant barrier; Majority of } \\
\text { participants; Prominent theme; Extreme } \\
\text { barriers; One of the most expressed; } \\
\text { Mentioned in all focus group }\end{array}$ \\
\hline
\end{tabular}

$2 *$ A default score of 2 was assigned for barriers that were not able to be rated, but were reported. 
Preprint version

6

7 Risk of bias for each of the included studies was assessed by two independent reviewers

$8(\mathrm{AB}, \mathrm{SC})$ for quantitative studies, two other independent reviewers for qualitative studies

9 (NBP, EN), and two independent reviewers for mixed studies (NR, AB) with the Mixed

10 Methods Appraisal Tool (MMAT-Version11), adapted for this review. Any discrepancies

11 were mediated by a third reviewer (AJR). Given the descriptive nature of our research

12 objectives, the following criteria were used for quantitative studies: 1) Is the sampling

13 strategy relevant to address the research question? 2) Is the sample representative of the

14 target population? 3) Are the measurements appropriate? 4) Is the risk of nonresponse bias

15 low? The 5 criteria for qualitative and mixed methods studies were those reported in the

16 MMAT (52, 53). Each criterion was assessed as having been fulfilled (1 point) or not

17 fulfilled/insufficient information for adequate assessment ( 0 point), leading to a global

18 score of 4 for quantitative studies, and 5 for qualitative and mixed studies. Scores were

19 then converted to percentage to facilitate between-studies comparison.

\section{$21 \quad$ Results}

22 Study Selection

23 The electronic searches generated 5,898 studies; which was reduced to 4,188 after

24 removing duplicates. Following this step, 3,857 records were excluded based on title and 25 abstract, with $52 \%$ of them because they did not present the outcomes of interest. Twenty26 six studies in total were included in this review (figure 1).

27 


\section{Figure 1. PRISMA Flow Diagram}

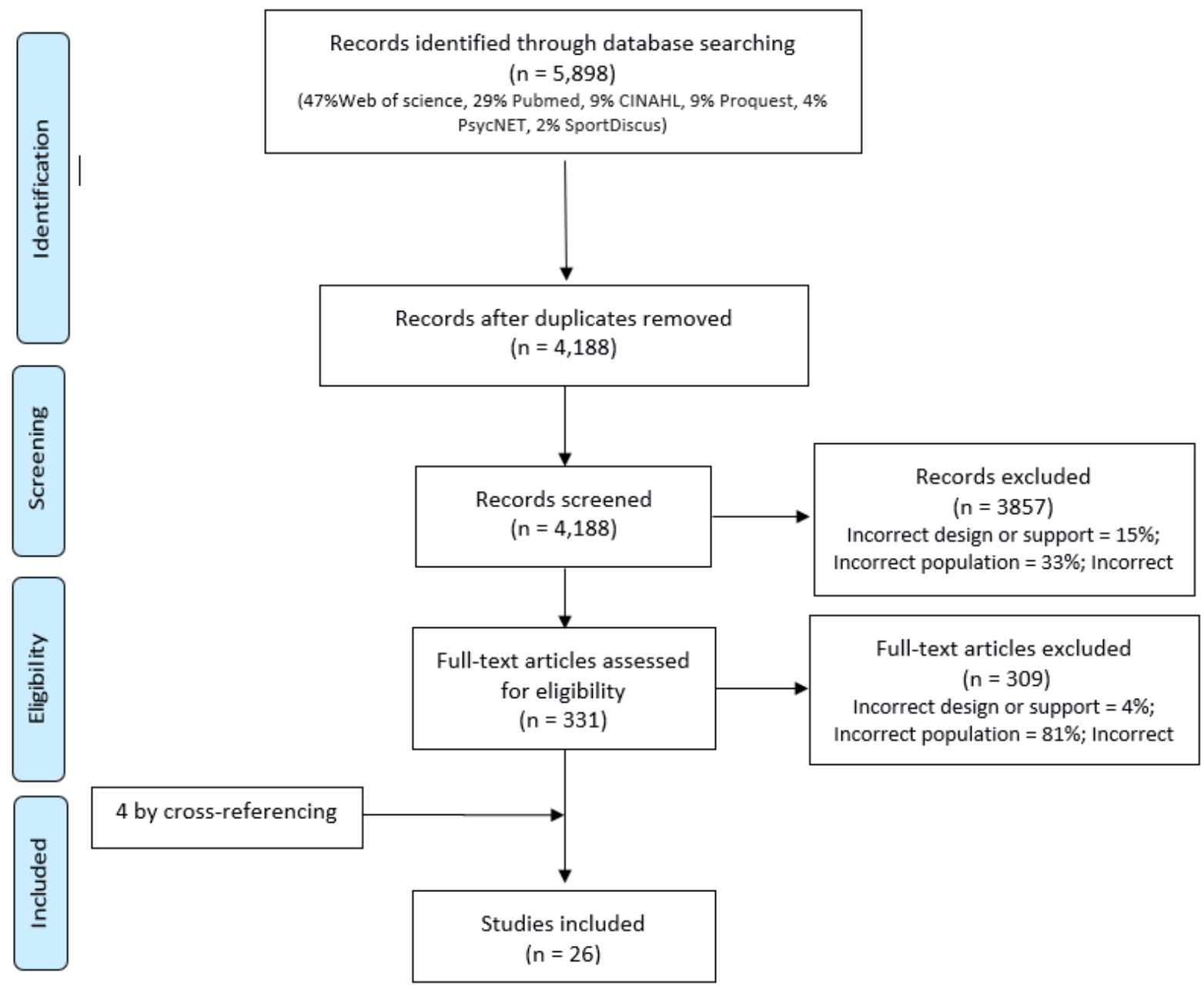




\section{Preprint version}

32

33 Table 2 describes study and participants' characteristics. Briefly, 13 quantitative studies 34

35

36

37 (50.0\%) (54-66), 10 qualitative studies (38.5\%) (67-76), and 3 mixed studies $(11.5 \%)$ (77-79) were included. Half of the studies were performed in the United States $(k=13)(55$, $57,58,60-62,64,67,68,72,77-79)$, and $34.6 \%$ published in the five last years $(2015-$ $2020 ; \mathrm{k}=9)(54,55,64,67-69,72,73,77)$. A total of 7,613 participants with obesity were assessed within the included studies $(\mathrm{k}=26)$, with a median age of 46 years old (range 37.8 62.0) ( $\mathrm{k}=10$ because information is missing for people with obesity in 16 studies). More than half of the studies included $>70 \%$ of women in their sample $(53.8 \% ; \mathrm{k}=14)(55,57$, $58,60-62,64,67,70,72,75,77-79), 38.5 \%$ included only women $(\mathrm{k}=10)(55,57,60-62$, $67,72,75,77,79)$, and $7.7 \%$ included only men $(k=2)(54,76)$.

Regarding our outcomes of interest, PA barriers were assessed in 23 studies $(88.5 \%)$ [10 quantitative, 10 qualitative, and 3 mixed studies] (54-62, 64, 67-79), motives in 11 studies (42.3\%) [2 quantitative, 8 qualitative, and 1 mixed studies] (54, 63, 67, 69-73, 75, 76, 79), and preferences in 4 studies $(15.4 \%)$ [3 quantitative and 1 qualitative studies] $(59,65,66$, 72).

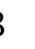

9

5

51

2

3


54 Table 2. Characteristics of the studies included $(\mathrm{k}=26)$

\begin{tabular}{|c|c|c|c|c|c|c|c|c|}
\hline \multirow{2}{*}{$\begin{array}{l}\text { (Reference) } \\
\text { Publication } \\
\text { Year } \\
\text { (Country) }\end{array}$} & \multirow{2}{*}{$\begin{array}{c}\text { Sample size } \\
(\% \text { of } \\
\text { women })\end{array}$} & \multicolumn{3}{|c|}{$\begin{array}{l}\text { People with obesity } \\
\text { [all sample data] }\end{array}$} & \multirow[b]{2}{*}{$\begin{array}{l}\text { Comorbidities (\%) and specific } \\
\text { characteristics }\end{array}$} & \multirow[b]{2}{*}{$\begin{array}{l}\text { Outcomes } \\
\text { assessed+ }\end{array}$} & \multirow[b]{2}{*}{ Methods/Tools } & \multirow[b]{2}{*}{$\begin{array}{c}\text { MMAT } \\
\text { scores }\end{array}$} \\
\hline & & $\%$ & $\begin{array}{c}\text { Age } \\
\text { years } \pm \text { SD or } \\
\text { (range })\end{array}$ & $\begin{array}{c}\text { BMI } \\
\mathrm{kg} / \mathrm{m}^{2} \pm \mathrm{SD} \\
\text { or }(\text { range })\end{array}$ & & & & \\
\hline \multicolumn{9}{|c|}{ Quantitative studies } \\
\hline $\begin{array}{l}\text { Ashton (54) } \\
2017 \\
\text { (Australia) }\end{array}$ & $\begin{array}{c}282 \\
(0 \%)\end{array}$ & $10 \%$ & $\begin{array}{l}\mathrm{NR} \\
{[22.3 \pm 2.1]}\end{array}$ & $\begin{array}{l}\mathrm{NR} \\
{[24.7 \pm 4.4]}\end{array}$ & NR & $\begin{array}{l}\text { Barriers } \\
\text { Motives }\end{array}$ & Online questionnaire & 25 \\
\hline $\begin{array}{l}\text { Masterson (55) } \\
2017 \\
\text { (USA) }\end{array}$ & $\begin{array}{l}630 \\
(100 \%)\end{array}$ & $41 \%$ & $49.7 \pm 15.4$ & NR & $\begin{array}{l}\text { T2D }(30.6 \%), \text { HBP }(25.7 \%) \\
\text { Mild }(15.8 \%) \text { and moderate-severe } \\
\text { depression }(26.1 \%) \\
\text { Urban Latinas }\end{array}$ & Barriers & $\begin{array}{l}5 \text { questions the Influences on } \\
\text { PA Instrument about barriers to } \\
\text { PA }\end{array}$ & 25 \\
\hline $\begin{array}{l}\text { Egan (56) } \\
2013 \\
\text { (Ireland) }\end{array}$ & $\begin{array}{l}145 \\
(36 \%)\end{array}$ & $100 \%$ & $59.0 \pm 11.0$ & $\begin{array}{l}34.0 \\
\text { (IQR: } 32.0- \\
37.5)\end{array}$ & T2D (100\%) & Barriers & List with scale & 0 \\
\hline $\begin{array}{l}\text { Genkinger (57) } \\
2006 \\
\text { (USA) }\end{array}$ & $\begin{array}{l}120 \\
(100 \%)\end{array}$ & $65 \%$ & $\begin{array}{l}\mathrm{NR} \\
{[48.0 \pm 11.0]}\end{array}$ & NR & $\begin{array}{l}\mathrm{NR} \\
\text { African American in church-based, PA } \\
\text { intervention }\end{array}$ & Barriers & $\begin{array}{l}\text { Adapted version of } \\
\text { Steinhardt/Dishman Barriers for } \\
\text { Habitual PA Scale }\end{array}$ & 50 \\
\hline $\begin{array}{l}\text { James (58) } \\
2008 \\
\text { (USA) }\end{array}$ & $\begin{array}{l}823 \\
(71 \%)\end{array}$ & $41 \%$ & $\begin{array}{l}\text { Class I: } 51.0 \\
(19-84) \\
\text { Class II: } 48.3 \\
(18-87)\end{array}$ & NR & $\begin{array}{l}\text { NR } \\
\text { African American and part of a } \\
\text { colorectal cancer prevention } \\
\text { intervention churches rural }\end{array}$ & Barriers & Phone questionnaire & 50 \\
\hline $\begin{array}{l}\text { Labrunee (59) } \\
2012 \\
\text { (France) }\end{array}$ & $\begin{array}{l}23 \\
(57 \%)\end{array}$ & $100 \%$ & $52.8 \pm 8.5$ & $\begin{array}{l}40.1 \pm 7.3 \\
\text { (control) } \\
39.3 \pm 9.9 \\
\text { (intervention) } \\
\end{array}$ & $\begin{array}{l}\text { Diabetes (100\%) } \\
\text { Enrolled in PA intervention }\end{array}$ & $\begin{array}{l}\text { Barriers } \\
\text { Preferences }\end{array}$ & Phone questionnaire & 0 \\
\hline $\begin{array}{l}\text { Napolitano (60) } \\
2011 \\
\text { (USA) }\end{array}$ & $\begin{array}{l}280 \\
(100 \%)\end{array}$ & $38 \%$ & $\begin{array}{l}\mathrm{NR} \\
{[47.3 \pm 10.7]}\end{array}$ & $\begin{array}{l}\mathrm{NR} \\
{[28.7 \pm 5.2]}\end{array}$ & $\begin{array}{l}\text { NR } \\
\text { Previously inactive women }\end{array}$ & Barriers & $\begin{array}{l}\text { Expected outcomes and barriers } \\
\text { for habitual PA scale }\end{array}$ & 25 \\
\hline $\begin{array}{l}\text { Rimmer (61) } \\
2010 \\
\text { (USA) }\end{array}$ & $\begin{array}{l}33 \\
(100 \%)\end{array}$ & $91 \%$ & $\begin{array}{l}\mathrm{NR} \\
{[60.1 \pm 10.1]}\end{array}$ & $\begin{array}{l}\mathrm{NR} \\
{[49.1 \pm 12.4]}\end{array}$ & $\begin{array}{l}\text { Arthritis (67\%), Multiple sclerosis } \\
(6 \%), \text { Stroke (6\%), Back problem (6\%) } \\
\text { Sedentary African-American }\end{array}$ & Barriers & $\begin{array}{l}\text { Barriers to PA Questionnaire for } \\
\text { People with Disabilities }\end{array}$ & 25 \\
\hline
\end{tabular}




\begin{tabular}{|c|c|c|c|c|c|c|c|c|}
\hline $\begin{array}{l}\text { Rye (62) } \\
2009 \\
\text { (USA) }\end{array}$ & $\begin{array}{l}702 \\
(100 \%)\end{array}$ & $60 \%$ & $\begin{array}{l}\mathrm{NR} \\
{[52.2 \pm 6.8]}\end{array}$ & NR & $\begin{array}{l}\text { NR } \\
\text { White, low-income women }\end{array}$ & Barriers & Questionnaire & 50 \\
\hline $\begin{array}{l}\text { Skov-Ettrup (63) } \\
2014 \\
\text { (Danemark) }\end{array}$ & $\begin{array}{l}55655 \\
(61 \%)\end{array}$ & $6 \%$ & NR & NR & $\begin{array}{l}\text { NR } \\
\text { PA during the past year }\end{array}$ & Motives & $\begin{array}{l}\text { Internet or paper-based } \\
\text { questionnaire }\end{array}$ & 25 \\
\hline $\begin{array}{l}\text { Stankevitz (64) } \\
2017 \\
\text { (USA) }\end{array}$ & $\begin{array}{l}124 \\
(93 \%)\end{array}$ & $100 \%$ & $45.0 \pm 9.0$ & $37.7 \pm 6.7$ & NR & Barriers & Internet or mail questionnaire & 25 \\
\hline $\begin{array}{l}\text { Burton (65) } \\
2012 \\
\text { (Australia) }\end{array}$ & $\begin{array}{l}7784 \\
(56 \%)\end{array}$ & $23 \%$ & $\begin{array}{l}\mathrm{NR} \\
{[(42-67)]}\end{array}$ & NR & NR & Preferences & Mail questionnaire & 75 \\
\hline $\begin{array}{l}\text { Short (66) } \\
2014 \\
\text { (Australia) }\end{array}$ & $\begin{array}{l}1137 \\
(50 \%)\end{array}$ & $30 \%$ & {$[52.8 \pm 16.3]$} & {$[30.0 \pm 14.7]$} & Chronic illness (46\%) & Preferences & Phone questionnaire & 50 \\
\hline \multicolumn{9}{|c|}{ Qualitative studies } \\
\hline $\begin{array}{l}\text { Bowen (67) } \\
2015 \\
\text { (USA) }\end{array}$ & $\begin{array}{l}9 \\
(100 \%)\end{array}$ & $78 \%$ & $\begin{array}{l}\mathrm{NR} \\
{[75.0 \pm 5.3]}\end{array}$ & $\begin{array}{l}\mathrm{NR} \\
{[27-41]}\end{array}$ & $67 \%$ reported using canes or walkers & $\begin{array}{l}\text { Barriers } \\
\text { Motives }\end{array}$ & Semi-structured interviews & 100 \\
\hline $\begin{array}{l}\text { Coe }(68) \\
2017 \\
\text { (USA) } \\
\end{array}$ & $\begin{array}{l}13 \\
(54 \%)\end{array}$ & $100 \%$ & $42.0(29-53)$ & $\begin{array}{l}52.5 \\
(37-81)\end{array}$ & $\begin{array}{l}100 \% \text { at least one comorbidity (HBP, } \\
\text { dyslipidemia, or T2D) } \\
\text { African American }\end{array}$ & Barriers & Focus group & 100 \\
\hline $\begin{array}{l}\text { Danielsen (69) } \\
2016 \\
\text { (Norway)* }\end{array}$ & $\begin{array}{l}8 \\
(63 \%)\end{array}$ & $100 \%$ & NR (35-63) & NR (37-60) & $\begin{array}{l}\text { Part of a 10-14 weeks inpatient } \\
\text { lifestyle modification program }\end{array}$ & $\begin{array}{l}\text { Barriers } \\
\text { Motives }\end{array}$ & Interviews & 100 \\
\hline $\begin{array}{l}\text { Guess (70) } \\
2012 \\
\text { (UK) }\end{array}$ & $\begin{array}{l}29 \\
(83 \%)\end{array}$ & $21 \%$ & $37.8 \pm 10.9$ & $46.8 \pm 5.6$ & $\begin{array}{l}\text { Attending dietetic clinics for weight } \\
\text { management }\end{array}$ & $\begin{array}{l}\text { Barriers } \\
\text { Motives }\end{array}$ & $\begin{array}{l}\text { Focus groups and semi- } \\
\text { structured interviews }\end{array}$ & 60 \\
\hline $\begin{array}{l}\text { Igelström (71) } \\
2012 \\
\text { (Sweden)* }\end{array}$ & $\begin{array}{l}15 \\
(47 \%)\end{array}$ & $100 \%$ & 62.0 (IQR 8.5) & 37.0 (IQR 5.0) & $\begin{array}{l}\text { Obstructive sleep apnea and CPAP } \\
\text { treatment }(100 \%)\end{array}$ & $\begin{array}{l}\text { Barriers } \\
\text { Motives }\end{array}$ & Semi-structured interviews & 100 \\
\hline $\begin{array}{l}\text { Joseph }(72) \\
2017 \\
\text { (USA) }\end{array}$ & $\begin{array}{l}25 \\
(100 \%)\end{array}$ & $100 \%$ & $38.5 \pm 7.8$ & $39.4 \pm 7.3$ & Sedentary lifestyle (100\%) & $\begin{array}{l}\text { Barriers } \\
\text { Motives } \\
\text { Preferences }\end{array}$ & Focus group & 100 \\
\hline
\end{tabular}




\begin{tabular}{|c|c|c|c|c|c|c|c|c|}
\hline $\begin{array}{l}\text { Lidegaard (73) } \\
2016 \\
\text { (Denmark) }\end{array}$ & $\begin{array}{l}28 \\
(46 \%)\end{array}$ & $86 \%$ & $\begin{array}{l}\mathrm{NR} \\
{[59.4 \pm 8.8]}\end{array}$ & $\begin{array}{l}\mathrm{NR} \\
{[34.4 \pm 5.0]}\end{array}$ & $\begin{array}{l}\text { T2D (100\%); Heart disease or } \\
\text { musculoskeletal disorders (79\%) }\end{array}$ & $\begin{array}{l}\text { Barriers } \\
\text { Motives }\end{array}$ & $\begin{array}{l}\text { Focus group }+ \text { probes in the } \\
\text { form of images, statements and } \\
\text { quotations regarding PA. }\end{array}$ & 100 \\
\hline $\begin{array}{l}\text { Piana (74) } \\
2013 \\
\text { (Italy) }\end{array}$ & $\begin{array}{l}80 \\
(63 \%)\end{array}$ & $100 \%$ & $53.2 \pm 12.2$ & $36.5 \pm 5.9$ & $\begin{array}{l}\text { HBP }(49 \%) ; \text { T2D }(35 \%) \\
\text { Coronary Heart Disease }(4 \%)\end{array}$ & Barriers & Focus group & 100 \\
\hline $\begin{array}{l}\text { Groven (75) } \\
2010 \\
\text { (Norway) }\end{array}$ & $5(100 \%)$ & $100 \%$ & NR (35-63) & NR (40-48) & Part of a weight loss program & $\begin{array}{l}\text { Barriers } \\
\text { Motives }\end{array}$ & Semi-structured interviews & 100 \\
\hline $\begin{array}{l}\text { Lewis (76) } \\
2011 \\
\text { (Australia) }\end{array}$ & $36(0 \%)$ & $100 \%$ & $46.0(21-69)$ & $37.1(30-61)$ & $\begin{array}{l}\text { HBP }(33.3 \%) \text {; Arthritis and joint } \\
\text { problems (30.6\%); Sleep apnea } \\
\text { (16.7\%); Diabetes (13.9\%), } \\
\text { Cardiovascular problems }(11.1 \%)\end{array}$ & $\begin{array}{l}\text { Barriers } \\
\text { Motives }\end{array}$ & Interviews & 60 \\
\hline \multicolumn{9}{|c|}{ Mixed-methods studies } \\
\hline $\begin{array}{l}\text { Adachi-Mejia } \\
(77) \\
2016 \\
\text { (USA)* }\end{array}$ & $\begin{array}{l}78 \\
(100 \%)\end{array}$ & $76 \%$ & $\begin{array}{l}\mathrm{NR} \\
{[52.8 \pm 14.5]}\end{array}$ & $\begin{array}{l}\mathrm{NR} \\
{[35.4 \pm 9.2]}\end{array}$ & $\begin{array}{l}\mathrm{NR} \\
\text { Enrolled in a lifestyle community- } \\
\text { based program for vulnerable } \\
\text { populations }\end{array}$ & Barriers & Survey + one open question & 80 \\
\hline $\begin{array}{l}\text { Lattimore (78) } \\
2011 \\
\text { (USA) }\end{array}$ & $\begin{array}{l}384 \\
(78 \%)\end{array}$ & $46 \%$ & $\begin{array}{l}\mathrm{NR} \\
{[50-75+]}\end{array}$ & NR & $\begin{array}{l}\text { NR } \\
\text { Adults } 50 \text { years and older }\end{array}$ & Barriers & Interviews & 80 \\
\hline \multirow[t]{2}{*}{$\begin{array}{l}\text { Leone (79) } \\
2013 \\
\text { (USA) }\end{array}$} & $\begin{array}{l}\text { Quanti } \\
195 \\
(100 \%)\end{array}$ & $51 \%$ & $\begin{array}{l}\mathrm{NR} \\
{[55.7 \pm 7.0]}\end{array}$ & $\begin{array}{l}\mathrm{NR} \\
{[35.7 \pm 7.0]}\end{array}$ & $\begin{array}{l}\mathrm{NR} \\
\text { Inactive white women over } 50 \text { years } \\
\text { old }\end{array}$ & $\begin{array}{l}\text { Barriers } \\
\text { Motives }\end{array}$ & Online survey & 80 \\
\hline & $\begin{array}{l}19 \\
(100 \%)\end{array}$ & $100 \%$ & $55(50-72)$ & $\begin{array}{l}36.0 \\
(28.2-46.6)\end{array}$ & & & Focus group & \\
\hline
\end{tabular}

* when country of recruitment was not reported country of the authors is reported; + = only outcomes assessed in people with obesity were reported in this column; BMI=body mass index; CPAP=Continuous positive air pressure; HBP= High blood pressure; MMAT=Mixed Methods Appraisal Tool; NR=not reported; PA=physical activity; T2D=type 2 diabetes. 
Preprint version

\section{Risk of Bias}

More than half of the quantitative studies have a MMAT score below $50 \%(61.5 \%, \mathrm{k}=8)$

(54-56, 59-61, 63, 64), and none in qualitative and mixed studies (see table 2 and supplemental Table S1). The scores of the quantitative studies below $50 \%$ are explained by the fact that non-probability sampling was performed in these studies, impacting the representativeness of the sample and our ability to know the nonresponse rate.

\section{Findings for Physical Activity Motives}

The 12 PA motives found were classified in different categories of motives: 6 psychosocial $(50.0 \%), 3$ socio-ecological $(25.0 \%)$ and 3 physical motives $(25.0 \%)$ (figure 2 and supplemental data $\mathrm{S} 2)$. More than half $(\mathrm{k}=7 / 12,58.3 \%)$ of PA motives comes from both quantitative and qualitative studies, $33.3 \%(\mathrm{k}=4 / 12)$ from qualitative studies only, and 8.3 $\%(\mathrm{k}=1 / 12)$ from quantitative study (Figure 2). In the different included studies, the three most reported PA motives among studies were weight management ( $\mathrm{k}=8 / 11,72.7 \%)$, energy/physical fitness $(\mathrm{k}=6 / 11,54.5 \%)$, and social support $(\mathrm{k}=6 / 11,54.5 \%)$ (Figure 2). In terms of ranking, the three PA motives with the highest scores of importance were also weight management (score=20), energy/physical fitness (score=13) and social support (score=12) (figure 3). 
Figure 2. Number of studies according to each categories of physical activity motives in people with obesity

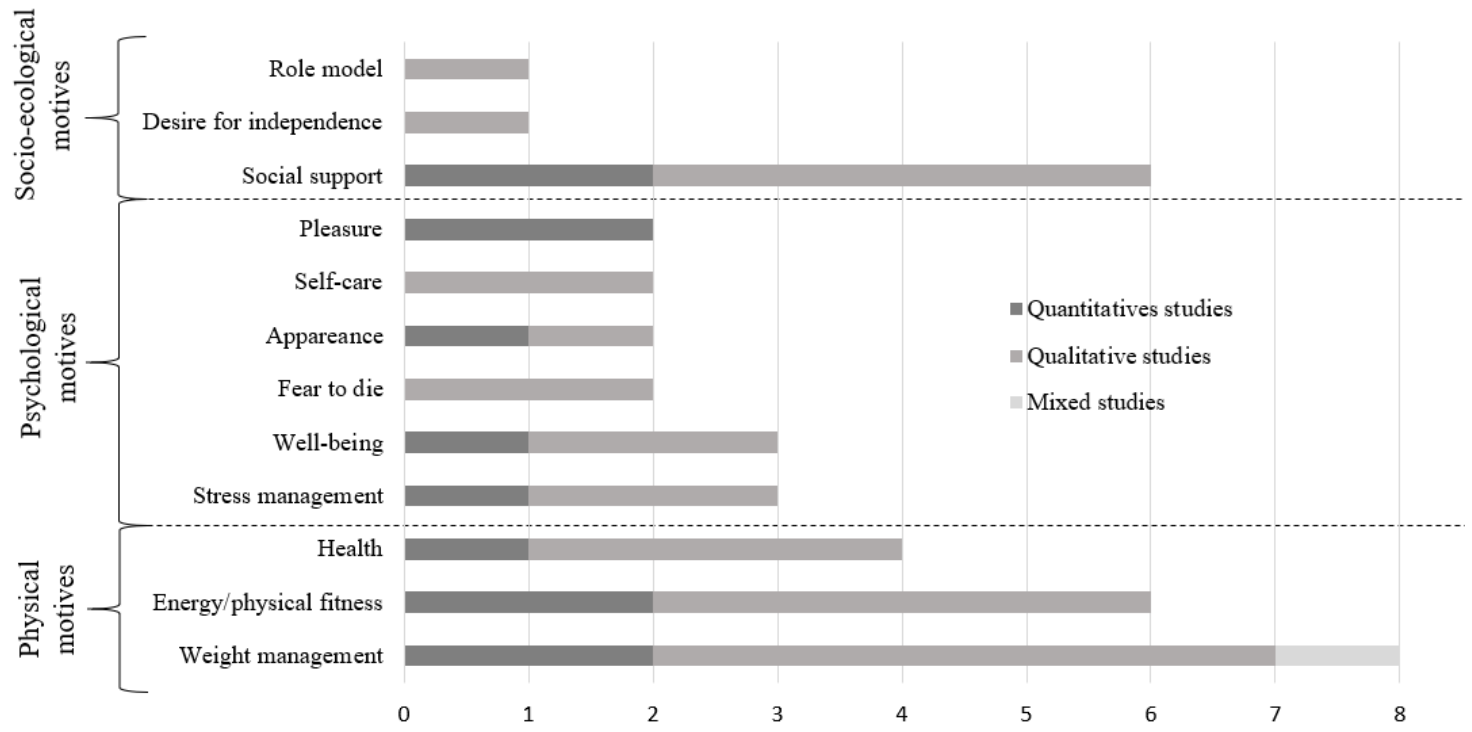

Figure 3. Importance scores of motives to physical activity in people with obesity

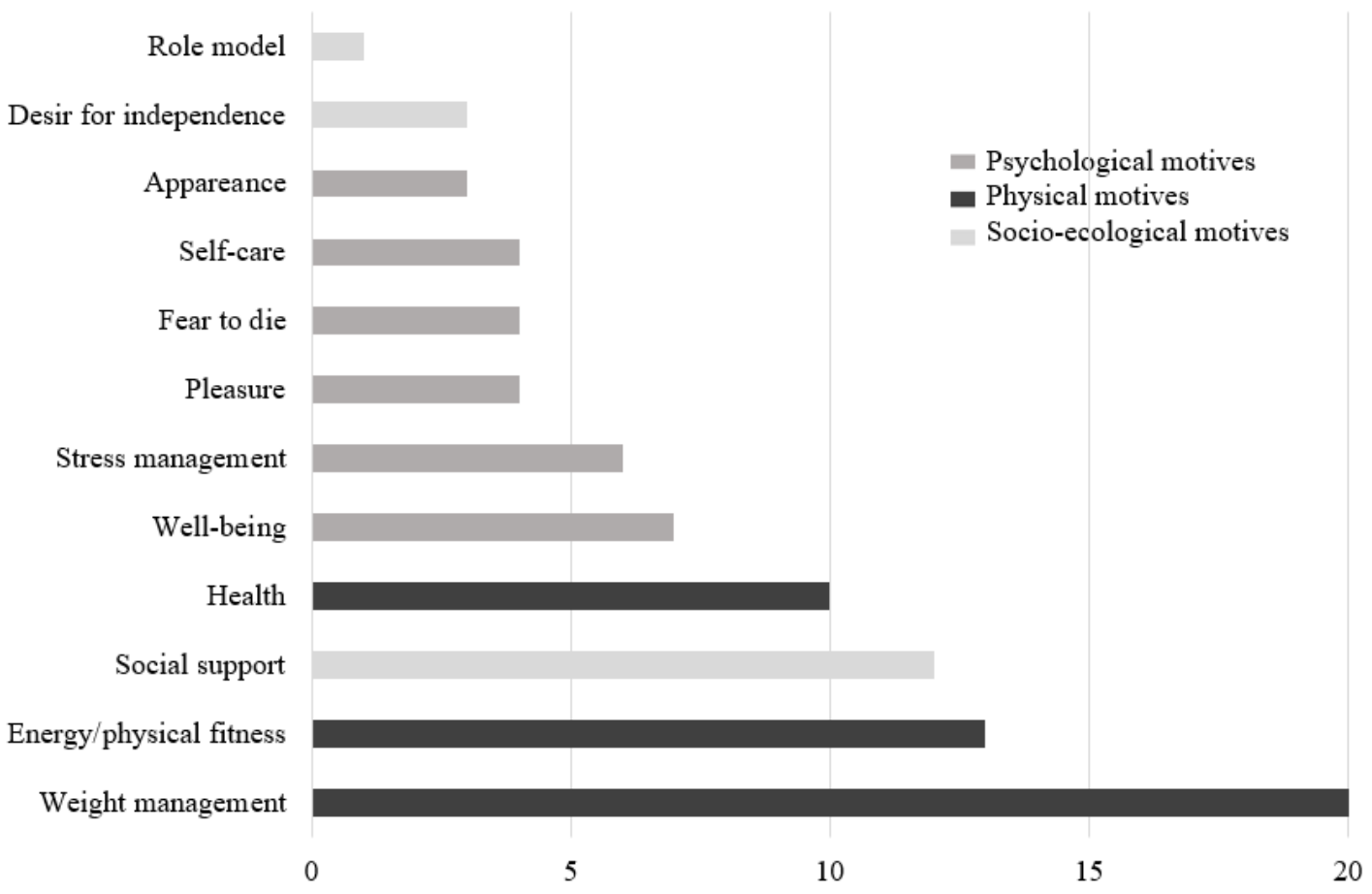


Findings for Physical Activity Barriers

Barriers were classified in three categories being socio-ecological barriers $(\mathrm{k}=9 ; 39.1 \%)$, psychological barriers $(\mathrm{k}=8 ; 34.8 \%)$, and physical barriers $(\mathrm{k}=6 ; 26.1 \%)$ (Figure 4 and supplemental data S3). Except for stigma (only qualitative studies), each PA barrier was studied in both quantitative and qualitative studies, and the most reported PA barriers among studies being lack of self-discipline/motivation ( $k=14 / 23,60.9 \%)$, pain/ physical discomfort $(\mathrm{k}=13 / 23,56.5 \%)$, and lack of access to equipment, facilities or professionals $(\mathrm{k}=13 / 23,56.5 \%)$ (Figure 4).

The three physical barriers to PA with the highest score of importance were pain/physical discomfort $($ score=31.5), fatigue/lack of energy $($ score=23.5) and poor health $($ score=20) (Figure 5). Regarding psychological barriers to PA, lack of self-discipline/motivation (score=32.5), lack of interest/enjoyment $($ score=17.7), and lack of skills/confidence (score $=17.0)$ were the most frequently reported (Figure 5). For socio-ecological barriers to PA, lack of time (score=28.5), lack of social support (score=22.0) and poor access to equipment, facilities or professionals (score=21.2) were the three barriers with the highest score of importance (Figure 5). 
Figure 4. Number of studies according to each categories of physical activity barriers in people with obesity

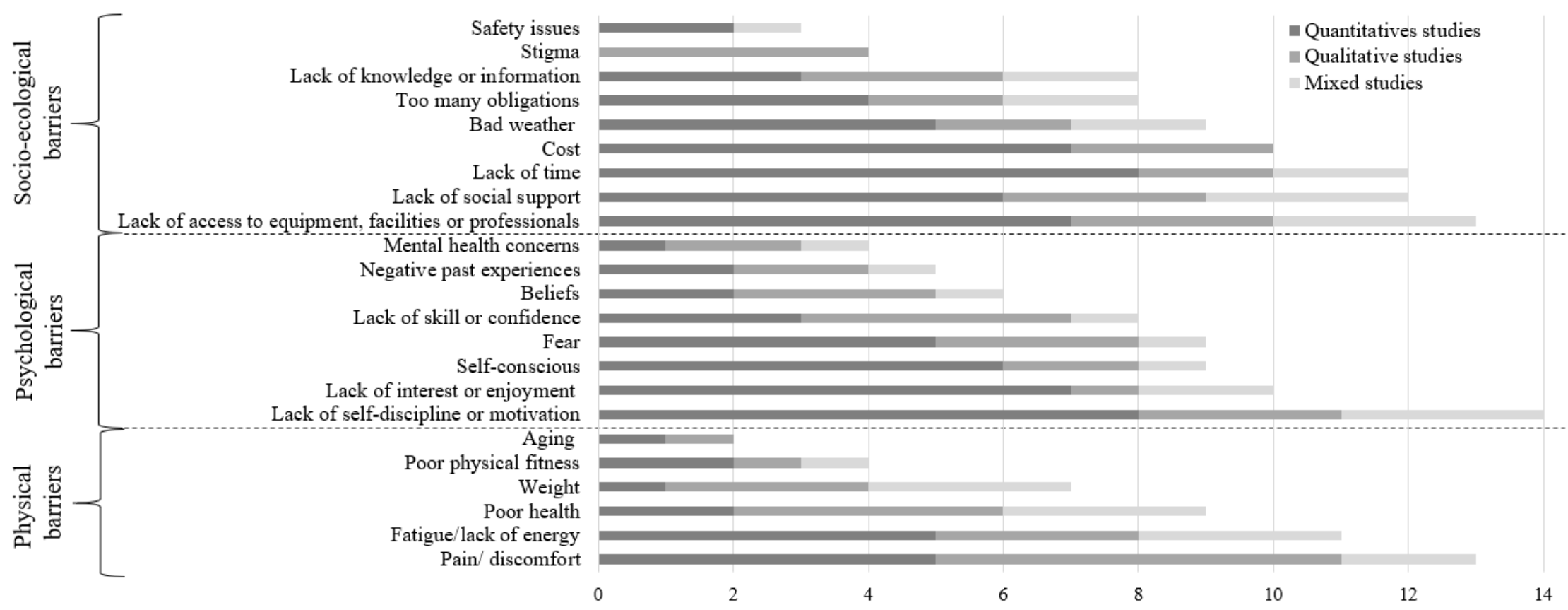


Figure 5. Importance scores of barriers to physical activity in people with obesity

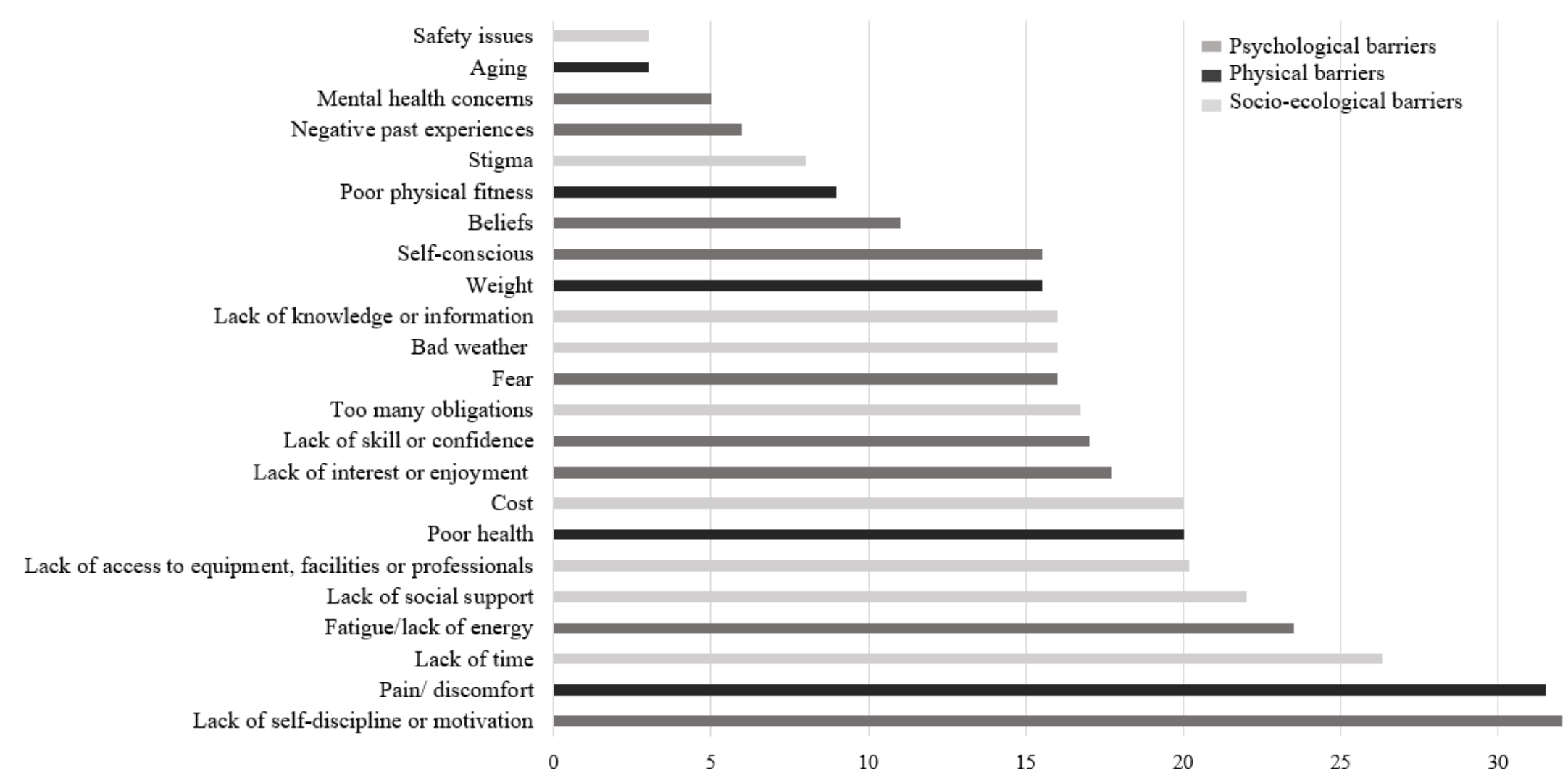




\section{Preprint version}

\section{Findings for Physical Activity Preferences}

Among the four studies reporting results on PA preferences in people with obesity, two provided information on PA preferences $(50 \%)(59,72)$, one on preferred PA context $(25$ $\%)(65)$, and one on preferred PA delivery mode for intervention (25\%) (66).

Labrunée et al. (2012) and Joseph et al. (2017) ranked preferred types of PA among people with obesity ( $n=23$ and 25, respectively), and found that walking was the most preferred activity for both men and women $(59,72)$. Otherwise, the other preferred PA were cycling, swimming and rowing in the Labrunée et al. (2012) study (59), and dance or Zumba, cycling, water activities, and martial arts in the Joseph et al. (2017) study which was performed among women with obesity (72). Resistance training was less often identified as a preferred type of PA (72).

Regarding the preferred PA context, Burton et al. (2012) examined it among 1781 middleaged adults with obesity (65). Results showed that $78 \%$ of participants preferred low-cost or no-cost PA, $61 \%$ preferred PA interventions that are not just about exercise, and $50 \%$ opted for PA with a format/routine set. Moreover, $26 \%, 15 \%$, and $16 \%$ of participants, respectively, preferred supervised, team-based and competitive PA. Nearly a quarter (23 $\%$ ) of participants reported a preference toward PA requiring skills and practice, and less than half of participants preferred vigorous PA (30\%) done at a fixed schedule time (43 $\%)$. In terms of location, $86 \%$ of participants reported a preference for PA that can be done close to home, and $59 \%$ preferred outdoor activities. Regarding social settings, $73 \%$ of individuals indicated a preference towards activities that can be performed alone, $49 \%$ preferred activities with people around their age and $28 \%$ with individuals with same sex. 


\section{Preprint version}

Short et al. (2014) rather analyzed the preferred PA intervention delivery mode, and provided the prevalence of people with obesity in four groups of people according to their most preferred mode of delivery ( $n=1137$ with 341 people with obesity): face-to-face program with an instructor (36\% of survey responders including $35 \%$ of people with obesity), group-based program (44\% of survey responders including $27 \%$ of people with obesity), program that can be done on their own using mailed and printed materials (11\% of survey responders including $26 \%$ of people with obesity), programs that can be done on their own using internet (9 \% of survey responders including $24 \%$ of people with obesity) (66).

\section{Comparison between BMI Classes}

Among the currently available studies $(\mathrm{k}=26)$, only a few have investigated whether PA motives $(\mathrm{k}=2)$, barriers $(\mathrm{k}=5)$ and preferences $(\mathrm{k}=2)$ differed among individuals with and without obesity. As shown in table 3 , weight management $(k=2 / 2)$, was the only motive that differed across BMI classes $(54,63)$. Studies reported that weight management was a more prevalent PA motivator in adults with obesity compared to adults without obesity (54, 63). Regarding PA barriers, though no difference between BMI classes were noted in socio-ecological barriers, weight $(\mathrm{k}=3 / 3 ;(60,77,79))$, lack of self-discipline/motivation $(\mathrm{k}=3 / 4 ;(58,60,77,78))$ and self-consciousness $(\mathrm{k}=3 / 3 ;(58,60,79)$ were more frequently reported by individuals with obesity than those without obesity.

Based on the two studies that have investigated associations of BMI or obesity with PA preferences $(65,66)$, social context seems particularly important among obese individuals. In fact, supervised (65) face-to-face (66) intervention was preferred to group-based 


\section{Preprint version}

intervention. However, in a context of group-based intervention, Burton et al. (2011) reported that homogeneous groups in terms of age and sex were preferred for individuals with a BMI greater than $30 \mathrm{~kg} / \mathrm{m}^{2}(65)$.

Table 3. Physical activity motives and barriers comparison across body mass index classes $(\mathrm{k}=7)$

\section{Motives}

$-$

\section{0}

$+$

$++$

\section{Physical factors $(k=2)$}

Weight management $(\mathrm{k}=2)$

(63)

Energy/physical fitness $(\mathrm{k}=2)$

(63)

Health $(\mathrm{k}=2)$

(54)

(54)

Psychological factors $(k=2)$

Fear to die/live longer $(\mathrm{k}=1)$

Well-being $(\mathrm{k}=1)$

Appearance $(\mathrm{k}=1)$

Pleasure $(\mathrm{k}=2)$

Stress management $(\mathrm{k}=1)$ $(54,63)$

Socio-ecological factors $(k=2)$

Socialize $(\mathrm{k}=1)$

Social influence $(\mathrm{k}=1)$

\section{Barriers}

0

\section{Physical factors $(k=4)$}

Poor health $(\mathrm{k}=4)$

Weight $(\mathrm{k}=3)$

Pain $(\mathrm{k}=1)$

$(63)^{*}$

Fatigue/lack of energy $(\mathrm{k}=4)$

Psychological factors $(k=5)$

Fear $(\mathrm{k}=2)$

Lack of self-discipline/motivation $(\mathrm{k}=4)$

Lack of interest/enjoyment $(\mathrm{k}=3)$

$(60,78)$

Mental health concerns $(\mathrm{k}=1)$

$(78)$

$(60,78,79)$

(77)

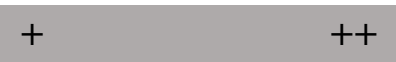

Lack of skills $(\mathrm{k}=1)$

(60)

Self-consciousness (k=3)

$(77,79)$

Negative past-experience $(\mathrm{k}=1)$

(78)

Beliefs (k=1)

$(60,77,79)$

(60)

Socio-ecological factors $(k=5)$

Lack of time $(\mathrm{k}=4)$

(78)

$(60,77)$

$(60,77)$

(55) 
Too many obligations $(\mathrm{k}=2)$

Lack of social support $(\mathrm{k}=4)$

Bad weather $(\mathrm{k}=3)$

Lack of knowledge/information $(\mathrm{k}=1)$

Cost $(\mathrm{k}=2)$

Poor access to facilities $(\mathrm{k}=4)$

- = less reported in people with obesity compared to normal and overweight people; 0 = no

more reported in people with overweight and obesity compared to normal weight people, $++=$ more reported in people with obesity compared

to normal and overweight people, ${ }^{*}$ Compared to normal weight adults only.
$(55,60)$

$(60,77,79)$

$(60,77,78)$

$(60)$

$(60)$

$(55)$

$(60,78,79)$

(55)

\section{Discussion:}

The objective of the present study was to investigate PA motives, barriers and preferences in people with obesity. To our knowledge, the present review is the first to systematically address these questions in this population. From the studies (i.e. 13 quantitative, 10 qualitative, and 3 mixed methods) included in this review, half were performed in the United States with a clear predominance of women participants. Barriers to PA were most frequently investigated $(\mathrm{k}=23)$ followed by PA motives $(\mathrm{k}=11)$, and preferences to PA $(\mathrm{k}=4)$.

The three most common PA motives reported by people with obesity, based on the scale of Clifford et al. (24), were weight management, energy/physical fitness and social support. Unsurprisingly, weight management was the most popular motive for PA in people with obesity, in accordance with previous qualitative review in people with severe obesity (28). In addition, weight management is the only motive in individuals with obesity, which differs significantly from adults without obesity according to our literature review $(54,63$, 79) (table 3). This motive is important for health professionals, and should be considered in PA interventions to rescale weight loss. Indeed, previous studies showed that PA alone produces only modest weight loss (7), and could therefore lead to PA discontinuation. So, 


\section{Preprint version}

to facilitate PA over time, people should be informed that in a weight management context, PA has a more important role in terms of weight loss maintenance or waist circumference reduction, $(6,7)$. If weight loss remains the main motive of the patient, an intervention focusing on both PA and diet/energy intake should be recommended (7). However, from a motivational point of view, it is critical to focus PA interventions on other motives than weight loss because, not only because PA is associated with several other health benefits (even in the absence of weight loss) $(10,80)$, but also because external PA motives are more likely to be associated with drop-out from PA interventions $(21,81)$.

The second most frequently reported PA motive in people with obesity was physical fitness improvement. This result is interesting given that it can be achieved through PA interventions (6). Moreover, previous studies highlighted physically fit people with obesity have a reduced rate of all-cause mortality compared to unfit people with and without obesity (82). However, weight and low physical fitness are also barriers to PA in people with obesity, as shown in our results (Figures 4 and 5). Nevertheless, these barriers can be reduced with PA counseling, and intervention tailored to physical fitness and weight related limitations of participants $(83,84)$.

According to our literature review, keys PA barriers were lack of motivation/selfdiscipline, pain/physical discomfort, and lack of time in people with obesity. When comparing BMI classes, weight and self-consciousness were more frequently reported as PA barriers by individuals with obesity than those without obesity.

We found that low motivation and lack of time are non-weight related PA barriers prominent in non-clinical and clinical populations $(24,47,85,86)$. However, studies 
included in our review seems to indicate that lack of self-discipline/motivation is more often reported in people with obesity (table 3). Behavioral interventions including motivational interviewing are effective options to address lack of motivation, given its efficacy to improve PA adherence (87). However, lack of time to exercise is harder to address because several time-use studies highlighted that this PA barrier is more likely to reflect PA being viewed as a low priority $(86,88)$. Moreover, people who have free time are not more active, thus simply helping them to find time for PA in their day might not improve PA in people with obesity (86). Indeed, time-related PA barrier are more a perception of "time pressure", and a personal choice to allocate time to other activities (86). Behavioral interventions in people with obesity are needed to support them to find motivation to change PA habits in this context. Several time-efficient solutions can be proposed like PA during transportation, PA during work break, reducing TV viewing, (86, 87). As a response to lack of time, it may be tempting to recommend high-intensity interval training to overcome time barriers, given the assumption that with higher intensity, exercise duration can be reduced, and seems more effective to reduce fat mass loss and increases physical fitness in people with obesity compared with traditional exercise (89-91). Nevertheless, there is a debate regarding the relevance of high- compared to moderateintensity exercise in adults living with obesity to increase PA levels (92). Indeed, strategies to increase the level of PA should not be solely based on weight loss or health-related benefits, but also on the potential of the strategy to modify lifestyle on a long-term basis (93). Knowing that adults living with obesity 1) avoid vigorous-intensity PA $(94,95)$, and 2) are willing to accept longer exercise durations if the intensity remains low (96) emphasizing high intensity could be counter productive. 


\section{Preprint version}

Regarding pain, the second most frequently reported PA barriers, people with obesity are more likely to suffer from pain $(97,98)$, explaining why it is an important barrier to PA in this population, consistently put forward in other studies (98), and also compared to other BMI classes (60). Indeed, from previous studies, a bidirectional association between pain and PA had been hypothesized in people with obesity. Musculoskeletal pain, the main source of pain described in qualitative studies can act as a functional limitation to engage and maintain PA (98). At the same time, regular PA can reduce chronic musculoskeletal pain in people with obesity, due to its potential positive impacts on inflammation, psychological outcomes (e.g., mood, pain catastrophizing, etc.), muscle strength and coordination (98). Nevertheless, PA for the pain management in people with obesity requires support to tailor the practice of PA and to assure safe and effective PA practice (98). The adjustment of PA volume (duration, intensity, frequency), joint range of motion during exercise, as well as the type of PA (non-impact PA) are valuable strategies that can be used for the pain management in order to increase PA adherence (98).

Weight is also a major physical obstacle to PA in people with obesity compared to people without obesity $(60,77,79)$. Interestingly, qualitative data from a study included in this review (79) revealed that women tend to perform more exercise when they lose weight because doing so gets easier. However, weight loss cannot be considered as facilitator given previous studies underlined that even after massive weight loss, people remain physically inactive $(99,100)$.

No conclusion on PA preferences can be drawn due to the small number of studies, and the different assessment of preferences (context vs. mode of delivery). However, walking 


\section{Preprint version}

seems to be preferred by people with obesity, as in the general North American population $(101,102)$, probably because walking required no specific skill, equipment or place, and can be integrated easily into everyday life (103). In addition, walking interventions are feasible and effective to improve the health of people with obesity (104). Thus, regular walking can be proposed by health professionals as an option in the management of obesity and inactivity. Considering the comparison between BMI classes, unfortunately, the paucity of data regarding how obesity classes affect PA preferences strongly limits generalization $(65,66)$. Nevertheless, some reflections emerge from this review and may be considered when PA recommendations are provided. Indeed, it appears that supervised (65) and individual (66) PA is preferred among individuals with obesity compared to their counterparts without obesity. Finally, while there is still inconsistency about the interest in group-based PA $(65,66)$, it seems that exercising with people of the same age and sex may be of importance for adults living with obesity. This suggests that feeling emotionally secure and socially accepted should not be underestimated (105). This is consistent with the fact that self-consciousness, a psychological barrier related to self-image and embarrassment during exercise, is a major PA barrier in adults living with obesity compared to other BMI classes (table 3). In addition, people with obesity declared that socialization, group belonging, family, professional or peer support motive them to engage, perform and maintain PA practice (table S2). This result is in accordance with several previous studies showing positive associations between social support with PA attendance and adherence $(106,107)$. Nevertheless, additional studies should be done in people with obesity, due to inverse results (no or negative association) in order to better understand the complex relationship between PA and social support $(106,107)$. Indeed, social support can 


\section{Preprint version}

be perceived as a PA barrier or motive according to people or context of practice, resulting in PA avoidance and isolation or PA adherence and socialization (28). Hence, it may be relevant to work on public health messages to successfully promote PA and favour a lower obesity stigmatization by providing a better training to health professionals (108).

The main strength of the present review is the systematic inclusion of both qualitative and quantitative literature, allowing a larger integration of PA barriers, motives, and preferences of people with obesity. However, some limitations should be considered to better interpret data. First, only English and French full texts have been included. A second limitation is due to the characteristics of the included studies. Indeed, half of studies comes from the United States, and all from occidental countries, and men with obesity are underrepresented. In addition, socioeconomic data of people with obesity are often missing in the included studies, not reported or only reported in all the sample, including people with and without obesity. However, it should be considered that ethnic diversity within the included studies is quite present, with $5(19.2 \%)$ studies performed in ethnic minority groups (Urban Latinas, and African American) $(55,57,58,61,68)$. Third, the use of a scale to quantify the importance of each barrier and motive is not the most accurate method compared to meta-analysis, but allowed in this context the integration of quantitative and qualitative studies, as well as to compare quantitative results with different kinds of questions (score vs. prevalence, Likert scale vs. yes/no answers). In addition, especially for PA motives, the relevance of this score is limited due to the high number of missing data (score 2 was attributed to more than $60 \%$ of the PA motives). Finally, publication bias could also affect our findings. 


\section{Preprint version}

Based on identified gaps in the literature, future research should focus on more representative sample of people with obesity. To date, most of the studies were conducted with women in occidental countries, and several included quantitative studies have selection bias. A strong need to determine PA preferences in people with obesity has been also identified, given only four studies are currently available. In addition, future works should provide data on the importance of PA motives, barriers and preferences in people with obesity. The use of a common unit (e.g., percentage rather than score) or the development of validated questionnaire in people with obesity could be useful to harmonize results and obtain better idea of the importance of each PA motives, barriers and preferences. Otherwise, self-consciousness, an important barrier in people with obesity (table 3), as well as stigmatization which was considered only in qualitative study according to our findings (figure 4) should be systematically considered in future studies. Finally, there is also a need to consider PA motives, barriers, and preferences differences according to gender, age, socioeconomic status, health status, PA level to better address diversity and specific needs. Indeed, differences between sexes have been already shown in people with overweight, with women reported more often being too fat, embarrassed, and with not good enough health as a PA barrier compared to men (109).

To conclude, PA motives and barriers are both weight and non-weight related in people with obesity. For this reason, weight loss can not be the only solution to remove PA barriers, and these should be addressed in PA interventions with the support of health professionals to facilitate PA initiation and maintenance. Further research is needed to investigate the PA preferences of people with obesity. Although, one size intervention does not fit all, the improvement of knowledge on PA barriers, motives and preferences would 
Preprint version

help health professionals to better address them, and develop intervention to reach the larger number of people with obesity in order to decrease physical inactivity in this population.

Acknowledgements: $\mathrm{AB}$ is the recipient of salary awards from the Fonds de recherche du Québec-Santé (FRQ-S). We would like to thank Simon Bouisset, librarian at University of Québec en Outaouais, Gatineau (Canada) for her contribution to the identification of information sources and database search.

Research funding: Canadian Health Research Institute NRF 155266 


\section{References}

1. Hales CM, Carroll MD, Fryar CD, Ogden CL. Prevalence of Obesity and Severe Obesity Among Adults: United States, 2017-2018. NCHS data brief. 2020(360):1-8.

2. Statistics Canada. Overweight and obese adults, 2018. Health Fact Sheets. 2019;Catalogue no.82-625-X.

3. Guh DP, Zhang W, Bansback N, Amarsi Z, Birmingham CL, Anis AH. The incidence of co-morbidities related to obesity and overweight: a systematic review and meta-analysis. BMC Public Health. 2009;9:88.

4. Ul-Haq Z, Mackay DF, Fenwick E, Pell JP. Meta-analysis of the association between body mass index and health-related quality of life among adults, assessed by the SF-36. Obesity (Silver Spring). 2013;21(3):E322-7.

5. Expert Panel Report: Guidelines (2013) for the management of overweight and obesity in adults. Obesity (Silver Spring). 2014;22 Suppl 2:S41-410.

6. Jakicic JM, Rogers RJ, Davis KK, Collins KA. Role of Physical Activity and Exercise in Treating Patients with Overweight and Obesity. Clin Chem. 2018;64(1):99-107.

7. Swift DL, Johannsen NM, Lavie CJ, Earnest CP, Church TS. The role of exercise and physical activity in weight loss and maintenance. Prog Cardiovasc Dis. 2014;56(4):441-7.

8. Janiszewski PM, Ross R. Physical activity in the treatment of obesity: beyond body weight reduction. Appl Physiol Nutr Metab. 2007;32(3):512-22.

9. Baillot A, Audet M, Baillargeon JP, Dionne IJ, Valiquette L, Rosa-Fortin MM, et al. Impact of physical activity and fitness in class II and III obese individuals: a systematic review. Obes Rev. 2014;15(9):721-39.

10. Pedersen BK, Saltin B. Exercise as medicine - evidence for prescribing exercise as therapy in 26 different chronic diseases. Scand J Med Sci Sports. 2015;25 Suppl 3:1-72.

11. Bastin A, Romain AJ, Marleau J, Baillot A. Health behaviours, intention and barriers to change among obesity classes I, II and III. Clin Obes. 2018;Accepted. 
12. Churilla JR, Johnson TM, Richardson MR, Williams BD, Rariden BS, Boltz AJ. Mode of physical activity participation by body mass index: 2015 behavioural risk factor surveillance system. Res Sports Med. 2018;26(2):147-57.

13. Schelling S, Munsch S, Meyer AH, Newark P, Biedert E, Margraf J. Increasing the motivation for physical activity in obese patients. Int J Eat Disord. 2009;42(2):130-8.

14. Joosten EA, DeFuentes-Merillas L, de Weert GH, Sensky T, van der Staak CP, de Jong CA. Systematic review of the effects of shared decision-making on patient satisfaction, treatment adherence and health status. Psychother Psychosom. 2008;77(4):219-26.

15. Callaghan P, Khalil E, Morres I, Carter T. Pragmatic randomised controlled trial of preferred intensity exercise in women living with depression. BMC Public Health. 2011;11:465.

16. Meyer JD, Ellingson LD, Koltyn KF, Stegner AJ, Kim JS, Cook DB. Psychobiological Responses to Preferred and Prescribed Intensity Exercise in Major Depressive Disorder. Med Sci Sports Exerc. 2016;48(11):2207-15.

17. van der Weijden T, Legare F, Boivin A, Burgers JS, van Veenendaal H, Stiggelbout AM, et al. How to integrate individual patient values and preferences in clinical practice guidelines? A research protocol. Implement Sci. 2010;5:10.

18. Williams DM. Exercise, affect, and adherence: an integrated model and a case for selfpaced exercise. J Sport Exerc Psychol. 2008;30(5):471-96.

19. Williams DM, Dunsiger S, Miranda R, Jr., Gwaltney CJ, Emerson JA, Monti PM, et al. Recommending self-paced exercise among overweight and obese adults: a randomized pilot study. Ann Behav Med. 2015;49(2):280-5.

20. Vartanian LR, Wharton CM, Green EB. Appearance vs. Health motives for exercise and for weight loss. Psychol Sport Exerc. 2012;13(3):251-6.

21. Teixeira PJ, Carraca EV, Markland D, Silva MN, Ryan RM. Exercise, physical activity, and self-determination theory: a systematic review. Int J Behav Nutr Phys Act. 2012;9:78. 
Preprint version

22. Heath GW, Parra DC, Sarmiento OL, Andersen LB, Owen N, Goenka S, et al. Evidencebased intervention in physical activity: lessons from around the world. Lancet. 2012;380(9838):272-81.

23. Olander EK, Fletcher H, Williams S, Atkinson L, Turner A, French DP. What are the most effective techniques in changing obese individuals' physical activity self-efficacy and behaviour: a systematic review and meta-analysis. Int J Behav Nutr Phys Act. 2013;10:29.

24. Clifford BK, Mizrahi D, Sandler CX, Barry BK, Simar D, Wakefield CE, et al. Barriers and facilitators of exercise experienced by cancer survivors: a mixed methods systematic review. Support Care Cancer. 2018;26(3):685-700.

25. Firth J, Rosenbaum S, Stubbs B, Gorczynski P, Yung AR, Vancampfort D. Motivating factors and barriers towards exercise in severe mental illness: a systematic review and metaanalysis. Psychol Med. 2016;46(14):2869-81.

26. Korkiakangas EE, Alahuhta MA, Laitinen JH. Barriers to regular exercise among adults at high risk or diagnosed with type 2 diabetes: a systematic review. Health Promot Int. 2009;24(4):416-27.

27. Rodrigues IB, Armstrong JJ, Adachi JD, MacDermid JC. Facilitators and barriers to exercise adherence in patients with osteopenia and osteoporosis: a systematic review. Osteoporosis Int. 2017;28(3):735-45.

28. Toft BS, Uhrenfeldt L. The lived experiences of being physically active when morbidly obese: A qualitative systematic review. Int J Qual Stud Health Well-being. 2015;10:28577.

29. Moher D, Liberati A, Tetzlaff J, Altman DG. Preferred reporting items for systematic reviews and meta-analyses: the PRISMA Statement. Open Med. 2009;3(3):e123-e30.

30. Denison FC, Weir Z, Carver H, Norman JE, Reynolds RM. Physical activity in pregnant women with Class III obesity: A qualitative exploration of attitudes and behaviours. Midwifery. 2015;31(12):1163-7. 
Preprint version

31. Bauer C, Graf C, Platschek AM, Struder HK, Ferrari N. Reasons, Motivational Factors, and Perceived Personal Barriers to Engagement in Physical Activity During Pregnancy Vary Within the BMI Classes: The Prenatal Prevention Project Germany. J Phys Act Health. 2018;15(3):204-11.

32. Krans EE, Chang JC. A will without a way: barriers and facilitators to exercise during pregnancy of low-income, African American women. Women Health. 2011;51(8):777-94.

33. Fazzino TL, Sporn NJ, Befort CA. A qualitative evaluation of a group phone-based weight loss intervention for rural breast cancer survivors: Themes and mechanisms of success. Support Care Cancer. 2016;24(7):3165-73.

34. Hardcastle SJ, Glassey R, Salfinger S, Tan J, Cohen P. Factors influencing participation in health behaviors in endometrial cancer survivors. Psychooncology. 2017;26(8):1099-104.

35. Paxton RJ, Nayak P, Taylor WC, Chang S, Courneya KS, Schover L, et al. AfricanAmerican breast cancer survivors' preferences for various types of physical activity interventions: a Sisters Network Inc. web-based survey. J Cancer Survivorship. 2014;8(1):31-8.

36. Piacentine LB, Robinson KM, Waltke LJ, Tjoe JA, Ng AV. Promoting Team-Based Exercise Among African American Breast Cancer Survivors. Western J Nursing Research. 2018;40(12):1885-902.

37. L. Cartwright, M. Reid, R. Hammersley, R. M. Walley. Barriers to increasing the physical activity of people with intellectual disabilities. Br J Learn Disabil. 2017;45(1):47-55.

38. Klingaman EA, Viverito KM, Medoff DR, Hoffmann RM, Goldberg RW. Strategies, barriers, and motivation for weight loss among veterans living with schizophrenia. Psychiatric Rehab J. 2014;37(4):270-6.

39. Baillot A, Mampuya WM, Dionne IJ, Comeau E, Meziat-Burdin A, Langlois MF. Impacts of Supervised Exercise Training in Addition to Interdisciplinary Lifestyle Management in Subjects Awaiting Bariatric Surgery: a Randomized Controlled Study. Obes Surg. 2016;26(11):2602-10. 
40. Baillot A, Vallee CA, Mampuya WM, Dionne IJ, Comeau E, Meziat-Burdin A, et al. Effects of a Pre-surgery Supervised Exercise Training 1 Year After Bariatric Surgery: a Randomized Controlled Study. Obes Surg. 2018; 28(4):955-962.

41. Beltrán-Carrillo VJ, Jiménez-Loaisa A, Jennings G, González-Cutre D, Navarro-Espejo N, Cervelló E. Exploring the socio-ecological factors behind the (in)active lifestyles of Spanish postbariatric surgery patients. Int J Qual Stud Health Well-being. 2019;14(1):1626180.

42. Bond DS, Thomas JG, Ryder BA, Vithiananthan S, Pohl D, Wing RR. Ecological Momentary Assessment of the Relationship between Intention and Physical Activity Behavior in Bariatric Surgery Patients. Int J Behav Med. 2011:1-6.

43. Dikareva A, Harvey WJ, Cicchillitti MA, Bartlett SJ, Andersen RE. Exploring Perceptions of Barriers, Facilitators, and Motivators to Physical Activity Among Female Bariatric Patients: Implications for Physical Activity Programming. Am J Health promotion. 2016;30(7):536-44.

44. Peacock JC, Sloan SS, Cripps B. A qualitative analysis of bariatric patients' post-surgical barriers to exercise. Obes Surg. 2014;24(2):292-8.

45. Wiklund M, Olsén MF, Willén C. Physical activity as viewed by adults with severe obesity, awaiting gastric bypass surgery. Physio Res Int. 2011;16(3):179-86.

46. Wouters EJ, Larsen JK, Zijlstra H, van Ramshorst B, Geenen R. Physical Activity After Surgery for Severe Obesity: The Role of Exercise Cognitions. Obes Surg. 2011;21(12):1-6.

47. Zabatiero J, Hill K, Gucciardi DF, Hamdorf JM, Taylor SF, Hagger MS, et al. Beliefs, Barriers and Facilitators to Physical Activity in Bariatric Surgery Candidates. Obes Surg. 2016;26(5):1097-109.

48. Zabatiero J, Smith A, Hill K, Hamdorf JM, Taylor SF, Hagger MS, et al. Do factors related to participation in physical activity change following restrictive bariatric surgery? A qualitative study. Obes Res Clin Pract. 2018;12(3):307-16.

49. Josbeno DA, Jakicic JM, Hergenroeder A, Eid GM. Physical activity and physical function changes in obese individuals after gastric bypass surgery. Surg Obes Relat Dis. 2010;6(4):361-6. 
Preprint version

50. Christiansen B, Borge L, Fagermoen MS. Understanding everyday life of morbidly obese adults-habits and body image. International journal of qualitative studies on health and well-being. $2012 ; 7: 17255$.

51. Thomas J, Harden A. Methods for the thematic synthesis of qualitative research in systematic reviews. . BMC Med Res Methodol. 2008;8(1):45.

52. Pluye P, Gagnon MP, Griffiths F, Johnson-Lafleur J. A scoring system for appraising mixed methods research, and concomitantly appraising qualitative, quantitative and mixed methods primary studies in Mixed Studies Reviews. Int J Nurs Stud. 2009;46(4):529-46.

53. Pace R, Pluye P, Bartlett G, Macaulay AC, Salsberg J, Jagosh J, et al. Testing the reliability and efficiency of the pilot Mixed Methods Appraisal Tool (MMAT) for systematic mixed studies review. Int J Nurs Stud. 2012;49(1):47-53.

54. Ashton LM, Hutchesson MJ, Rollo ME, Morgan PJ, Collins CE. Motivators and Barriers to Engaging in Healthy Eating and Physical Activity. Am J Men Health. 2017;11(2):330-43.

55. Masterson Creber RM, Fleck E, Liu J, Rothenberg G, Ryan B, Bakken S. Identifying the Complexity of Multiple Risk Factors for Obesity Among Urban Latinas. J Immigrant Minority Health. 2017;19(2):275-84.

56. Egan AM, Mahmood WA, Fenton R, Redziniak N, Kyaw Tun T, Sreenan S, et al. Barriers to exercise in obese patients with type 2 diabetes. QJM. 2013;106(7):635-8.

57. Genkinger JM, Jehn ML, Sapun M, Mabry I, Young DR. Does weight status influence perceptions of physical activity barriers among African-American women? Ethn Dis. 2006;16(1):78-84.

58. James AS, Leone L, Katz ML, McNeill LH, Campbell MK. Multiple health behaviors among overweight, class I obese, and class II obese persons. Ethn Dis. 2008;18(2):157-62.

59. Labrunee M, Antoine D, Verges B, Robin I, Casillas JM, Gremeaux V. Effects of a homebased rehabilitation program in obese type 2 diabetics. Annals of physical and rehabilitation medicine. 2012;55(6):415-29. 
Preprint version

60. Napolitano MA, Papandonatos GD, Borradaile KE, Whiteley JA, Marcus BH. Effects of weight status and barriers on physical activity adoption among previously inactive women. Obesity (Silver Spring). 2011;19(11):2183-9.

61. Rimmer JH, Hsieh K, Graham BC, Gerber BS, Gray-Stanley JA. Barrier removal in increasing physical activity levels in obese African American women with disabilities. J Women Health. 2010;19(10):1869-76.

62. Rye JA, Rye SL, Tessaro I, Coffindaffer J. Perceived barriers to physical activity according to stage of change and body mass index in the west virginia wisewoman population. Women Health Issues. 2009;19(2):126-34.

63. Skov-Ettrup LS, Petersen CB, Curtis T, Lykke M, Christensen AI, Tolstrup JS. Why do people exercise? A cross-sectional study of motives to exercise among Danish adults. Public Health. 2014;128(5):482-4.

64. Stankevitz K, Dement J, Schoenfisch A, Joyner J, Clancy SM, Stroo M, et al. Perceived Barriers to Healthy Eating and Physical Activity Among Participants in a Workplace Obesity Intervention. J Occupational Environmental Med. 2017;59(8):746-51.

65. Burton NW, Khan A, Brown WJ. How, where and with whom? Physical activity context preferences of three adult groups at risk of inactivity. Br J Sports Med. 2012;46(16):1125-31.

66. Short C, Vandelanotte C, Duncan M. Individual characteristics associated with physical activity intervention delivery mode preferences among adults. Int $\mathrm{J}$ Behav Nut Phys Act. 2014;11(25):1-10.

67. Bowen PG, Eaves YD, Vance DE, Moneyham LD. A phenomenological study of obesity and physical activity in southern African American older women. Journal of aging and physical activity. 2015;23(2):221-9.

68. Coe WH, Redmond L, Parisi JM, Bowie JV, Liu EY, Ng TY, et al. Motivators, Barriers, and Facilitators to Weight Loss and Behavior Change Among African American Adults in Baltimore City: A Qualitative Analysis. J Natl Med Assoc. 2017;109(2):79-85. 
Preprint version

69. Danielsen KK, Sundgot-Borgen J, Rugseth G. Severe Obesity and the Ambivalence of Attending Physical Activity: Exploring Lived Experiences. Qual Health Res. 2016;26(5):685-96.

70. Guess N. A qualitative investigation of attitudes towards aerobic and resistance exercise amongst overweight and obese individuals. BMC Res Notes. 2012;5:191.

71. Igelstrom H, Martin C, Emtner M, Lindberg E, Asenlof P. Physical activity in sleep apnea and obesity-personal incentives, challenges, and facilitators for success. Behav Sleep Med. 2012;10(2):122-37.

72. Joseph RP, Ainsworth BE, Mathis L, Hooker SP, Keller C. Utility of Social Cognitive Theory in Intervention Design for Promoting Physical Activity among African-American Women: A Qualitative Study. Am J Health Behav. 2017;41(5):518-33.

73. Lidegaard LP, Schwennesen N, Willaing I, Faerch K. Barriers to and motivators for physical activity among people with Type 2 diabetes: patients' perspectives. Diabet Med. 2016;33(12):1677-85.

74. Piana N, Battistini D, Urbani L, Romani G, Fatone C, Pazzagli C, et al. Multidisciplinary lifestyle intervention in the obese: its impact on patients' perception of the disease, food and physical exercise. Nut Metab Cardiovasc Dis. 2013;23(4):337-43.

75. Groven KS, Engelsrud G. Dilemmas in the process of weight reduction: Exploring how women experience training as a means of losing weight. Int J Qual Stud Health Well-being. 2010;5. 76. Lewis S, Thomas SL, Hyde J, Castle DJ, Komesaroff PA. A qualitative investigation of obese men's experiences with their weight. Am J Health Behav. 2011;35(4):458-69.

77. Adachi-Mejia AM, Schifferdecker KE. A mixed-methods approach to assessing barriers to physical activity among women with class I, class II, and class III obesity. Public Health. 2016;139:212-5.

78. Lattimore D, Wilcox S, Saunders R, Griffin S, Fallon E, Hooker S, et al. Self-Reported Barriers of Middle-Aged and Older Adults Entering a Home-Based Physical Activity Program. Calif J Health Prom. 2011;9(2):15-28. 
Preprint version

79. Leone LA, Ward DS. A mixed methods comparison of perceived benefits and barriers to exercise between obese and nonobese women. J Phys Act Health. 2013;10(4):461-9.

80. Gaesser GA, Angadi SS, Sawyer BJ. Exercise and diet, independent of weight loss, improve cardiometabolic risk profile in overweight and obese individuals. Phys Sportsmed. 2011;39(2):87-97.

81. Ryan RM, Deci EL. Self-determination theory and the facilitation of intrinsic motivation, social development, and well-being. Am Psychol. 2000;55(1):68-78.

82. Barry VW, Baruth M, Beets MW, Durstine JL, Liu J, Blair SN. Fitness vs. fatness on allcause mortality: a meta-analysis. Prog Cardiovasc Dis. 2014;56(4):382-90.

83. McInnis KJ, Franklin BA, Rippe JM. Counseling for physical activity in overweight and obese patients. Am Fam Physician. 2003;67(6):1249-56.

84. Brinks J, Franklin B. Suboptimal Exercise Compliance: Common Barriers to an Active Lifestyle and Counseling Strategies to Overcome Them. Am J Lifestyle Med. 2011;5(3):253-61.

85. Toscos T, Consolvo S, McDonald DW. Barriers to physical activity: a study of selfrevelation in an online community. J Med Syst. 2011;35(5):1225-42.

86. Rebar AL, Johnston R, Paterson JL, Short CE, Schoeppe S, Vandelanotte C. A Test of How Australian Adults Allocate Time for Physical Activity. Behav Med. 2017:1-6.

87. Stonerock GL, Blumenthal JA. Role of Counseling to Promote Adherence in Healthy Lifestyle Medicine: Strategies to Improve Exercise Adherence and Enhance Physical Activity. Prog Cardiovasc Dis. 2017;59(5):455-62.

88. Sturm R, Cohen D. Free Time and Physical Activity Among Americans 15 Years or Older: Cross-Sectional Analysis of the American Time Use Survey. Prev Chronic Dis. 2019;16:190017.

89. Turk Y, Theel W, Kasteleyn MJ, Franssen FME, Hiemstra PS, Rudolphus A, et al. High intensity training in obesity: a Meta-analysis. Obes Sci Pract. 2017;3(3):258-71. 
Preprint version

90. Wewege M, van den Berg R, Ward RE, Keech A. The effects of high-intensity interval training vs. moderate-intensity continuous training on body composition in overweight and obese adults: a systematic review and meta-analysis. Obes Rev. 2017;18(6):635-46.

91. Sultana RN, Sabag A, Keating SE, Johnson NA. The Effect of Low-Volume High-Intensity Interval Training on Body Composition and Cardiorespiratory Fitness: A Systematic Review and Meta-Analysis. Sports Med. 2019;49(11):1687-721.

92. Ekkekakis P, Vazou S, Bixby WR, Georgiadis E. The mysterious case of the public health guideline that is (almost) entirely ignored: call for a research agenda on the causes of the extreme avoidance of physical activity in obesity. Obes Rev. 2016;17(4):313-29.

93. Goldberg JH, King AC. Physical activity and weight management across the lifespan. Ann Rev Pub Health. 2007;28:145-70.

94. Hansen BH, Holme I, Anderssen SA, Kolle E. Patterns of objectively measured physical activity in normal weight, overweight, and obese individuals (20-85 years): a cross-sectional study. PLoS One. 2013;8(1):e53044.

95. Scheers T, Philippaerts R, Lefevre J. Patterns of physical activity and sedentary behavior in normal-weight, overweight and obese adults, as measured with a portable armband device and an electronic diary. Clin Nutr. 2012;31(5):756-64.

96. Fogelholm M, Kukkonen-Harjula K, Nenonen A, Pasanen M. Effects of walking training on weight maintenance after a very-low-energy diet in premenopausal obese women: a randomized controlled trial. Arch Intern Med. 2000;160(14):2177-84.

97. Stone AA, Broderick JE. Obesity and pain are associated in the United States. Obesity (Silver Spring). 2012;20(7):1491-5.

98. Zdziarski LA, Wasser JG, Vincent HK. Chronic pain management in the obese patient: a focused review of key challenges and potential exercise solutions. J Pain Res. 2015;8:63-77. 
99. King WC, Chen JY, Bond DS, Belle SH, Courcoulas AP, Patterson EJ, et al. Objective assessment of changes in physical activity and sedentary behavior: Pre- through 3 years postbariatric surgery. Obesity (Silver Spring). 2015;23(6):1143-50.

100. Bond DS, Jakicic JM, Unick JL, Vithiananthan S, Pohl D, Roye GD, et al. Pre- to postoperative physical activity changes in bariatric surgery patients: self report vs. objective measures. Obesity (Silver Spring, Md). 2010;18(12):2395-7.

101. Watson KB, Frederick GM, Harris CD, Carlson SA, Fulton JE. U.S. Adults' Participation in Specific Activities: Behavioral Risk Factor Surveillance System--2011. J Phys Act Health. 2015;12 Suppl 1:S3-10.

102. Gilmour H. Physically active Canadians. . Health Reports. 2007;18(3):45.

103. Kadir MA, Kubacki K, Rundle-Thiele S. Perceived benefits and barriers of walking among overweight and obese adults. Health Mark Q. 2019;36(1):54-70.

104. Mabire L, Mani R, Liu L, Mulligan H, Baxter D. The Influence of Age, Sex and Body Mass Index on the Effectiveness of Brisk Walking for Obesity Management in Adults: A Systematic Review and Meta-Analysis. J Phys Act Health. 2017;14(5):389-407.

105. Thomas S, Lewis S, Hyde J, Castle D, Komesaroff P. The solution needs to be complex. Obese adults' attitudes about the effectiveness of individual and population based interventions for obesity. BMC Public Health 2010;10:420.

106. Bauman AE, Reis RS, Sallis JF, Wells JC, Loos RJ, Martin BW. Correlates of physical activity: why are some people physically active and others not? Lancet. 2012;380(9838):258-71.

107. Scarapicchia TMF, Amireault S, Faulkner G, Sabiston CM. Social support and physical activity participation among healthy adults: A systematic review of prospective studies. Int Rev Sport Exerc Psychol. 2017;10(1):50-83.

108. The British Psychological Society. Psychological Perspectives on Obesity: Addressing Policy. Pract Res Priorities. 2019:1-64. 
Preprint version

109. Ball K, Crawford D, Owen N. Too fat to exercise? Obesity as a barrier to physical activity. Austral New Zealand J Pub Health. 2000;24(3):331-3 3p. 
S1. Search equation

\section{PUBMED with MesH-terms}

(((Exercise[MeSH Terms]) AND (((((Motiv*) OR preference*) OR barrier*) OR facilitator*) OR obstacle*)) AND Obesity[MeSH Terms]) AND humans [MeSH Terms] Limits: humans / English or French / adult 19+ years

\section{PUBMED with keywords}

(Exercise*[All Fields] OR Endurance [All Fields] OR Aerobic* [All Fields] OR Resistance adj1(activit* or train*)[All Fields] OR Muscl* adj2 (exercis* or strength) [All Fields] OR Sport [All Fields] OR Physical adj3 (activit* or train* or therap* or rehabili*) [All Fields] OR Relaxation [All Fields] OR Flexibility [All Fields] OR Stretch* [All Fields] OR Walk*[All Fields] OR Yoga[All Fields]) AND (obes*[Title/Abstract]) AND (motiv*[All Fields] OR preference*[All Fields] OR barrier*[All Fields] OR facilitator*[All Fields] OR obstacle*[All Fields])

Filters : English/French; Adult:19+; Humans

\section{Cinahl}

(MH "Obesity") AND ((MH "Exercise") OR (MH "Physical Education and Training") OR (MH "Physical Fitness") OR (MH "Physical Activity") OR (MH "Therapeutic Exercise") OR (MH "Yoga") OR (MH "Dance Therapy") OR (MH "Tai Chi") OR (MH "Sports")) AND ((TX "Motiv*") OR (TX preference*) OR (TX barrier*) OR (TX facilitator*) OR (TX obstacle*))

Opérateurs de restriction : All Adult; Peer Reviewed; English, French

\section{PsycNET}

((Any Field: (Weightlifting)) $O R$ (Any Field: (Physical Activity)) $O R($ Index Terms: (Aerobic Exercise)) OR (Index Terms: (exercise)) OR (Any Field: (Yoga)) $) A N D$ ((Index Terms: (obesity))) AND ((Any Field: (motiv*)) OR (Any Field: (obstacle*)) OR (Any Field: (preference*)) OR (Any Field: (barrier*)) AND (Any Field: (facilitator*))) AND Publication Type: Peer Reviewed Journal AND Age Group: Adulthood (18 yrs \& older)

\section{Sportdiscus}

SU "OBESITY" AND SU "EXERCISE" AND (motiv* OR preference* OR barrier* OR facilitator* OR obstacle*)

Limiters: Peer Reviewed; English, French

\section{Web of science}

TOPIC: (exercis* OR endurance OR aerobic* OR "resistance activit*" OR "resistance train*" OR "Muscl* exercis*" OR "Muscl* strenght*" OR Sport OR "Physical activit*" OR "physical train*" OR "physical therap*" OR "Physical rehabili*" OR Relaxation OR Flexibility OR Stretch* OR walk OR yoga) AND TOPIC: (motiv* OR barrier* OR facilitator* OR obstacle* OR preference*)

AND TOPIC: (obes*)

Refined by: LANGUAGES: ( ENGLISH OR FRENCH ) AND DOCUMENT TYPES: ( ARTICLE ) AND RESEARCH AREAS: ( HEALTH CARE SCIENCES SERVICES OR OBSTETRICS GYNECOLOGY OR PUBLIC ENVIRONMENTAL OCCUPATIONAL 
HEALTH OR REPRODUCTIVE BIOLOGY OR ENDOCRINOLOGY METABOLISM OR SOCIAL SCIENCES OTHER TOPICS OR NUTRITION DIETETICS OR SOCIOLOGY OR BEHAVIORAL SCIENCES OR MEDICAL LABORATORY TECHNOLOGY OR PSYCHOLOGY OR SOCIAL WORK OR RESEARCH EXPERIMENTAL MEDICINE OR ORTHOPEDICS OR GENERAL INTERNAL MEDICINE OR SPORT SCIENCES OR SURGERY OR FOOD SCIENCE TECHNOLOGY OR LIFE SCIENCES BIOMEDICINE OTHER TOPICS OR NEUROSCIENCES NEUROLOGY OR COMMUNICATION OR PSYCHIATRY OR ENVIRONMENTAL SCIENCES ECOLOGY OR NURSING OR REHABILITATION OR CARDIOVASCULAR SYSTEM CARDIOLOGY OR RESPIRATORY SYSTEM OR EDUCATION EDUCATIONAL RESEARCH )

\section{PROQUEST - Physical Education Index}

SU("Exercise") AND SU("Obesity") AND (all(barrier*) OR all(preference*) OR all("facilitator*") OR all("obstacle*") OR all ("Motiv*"))

Limits : peer reviewed + English + humans 
Table S1: Risk of bias assessed with the Mixed Methods Appraisal Tool Quantitative studies

\begin{tabular}{|c|c|c|c|c|c|c|}
\hline & $\begin{array}{l}\text { 1. Is the sampling strategy } \\
\text { relevant to address the } \\
\text { research question? }\end{array}$ & $\begin{array}{l}\text { 2. Is the sample representative } \\
\text { of the target population? }\end{array}$ & $\begin{array}{l}\text { 3. Are the } \\
\text { measurements } \\
\text { appropriate? }\end{array}$ & 4. Is the risk of nonresponse bias low? & & $\begin{array}{l}\text { Total } \\
\text { score } \\
\%\end{array}$ \\
\hline Ashton (54) & No & No & Yes & Can't tell & & 25 \\
\hline Masterson (55) & No & No & Yes & Can't tell & & 25 \\
\hline Egan (56) & No & Can't tell & No & Can't tell & & 0 \\
\hline Genkinger (57) & No & No & Yes & Yes & & 50 \\
\hline James (58) & No & No & Yes & Yes & & 50 \\
\hline Labrunee (59) & No & No & No & Can't tell & & 0 \\
\hline Napolitano (60) & No & No & Yes & Can't tell & & 25 \\
\hline Rimmer (61) & No & No & Yes & Can't tell & & 25 \\
\hline Rye (62) & Yes & Yes & No & Can't tell & & 50 \\
\hline Skov-Ettrup (63) & Yes & No & No & No & & 25 \\
\hline Stankevitz (64) & No & No & Yes & No & & 25 \\
\hline Burton (65) & Yes & Yes & No & Yes & & 75 \\
\hline Short (66) & Yes & No & Yes & No & & 50 \\
\hline \multicolumn{7}{|c|}{ Qualitative studies } \\
\hline & $\begin{array}{l}\text { 1. Is the qualitative approach } \\
\text { appropriate to answer the } \\
\text { research question? }\end{array}$ & $\begin{array}{l}\text { 2. Are the qualitative data } \\
\text { collection methods adequate } \\
\text { to address the research } \\
\text { question? }\end{array}$ & $\begin{array}{l}\text { 3. Are the findings } \\
\text { adequately derived } \\
\text { from the data? }\end{array}$ & $\begin{array}{l}\text { 4. Is the interpretation of results } \\
\text { sufficiently substantiated by data? }\end{array}$ & $\begin{array}{l}\text { 5. Is there coherence between } \\
\text { qualitative data sources, } \\
\text { collection, analysis and } \\
\text { interpretation? }\end{array}$ & \\
\hline Bowen (67) & Yes & Yes & Yes & Yes & Yes & 100 \\
\hline Coe (68) & Yes & Yes & Yes & Yes & Yes & 100 \\
\hline Danielsen (69) & Yes & Yes & Yes & Yes & Yes & 100 \\
\hline Guess (70) & Yes & Yes & Yes & No & No & 60 \\
\hline Igelström (71) & Yes & Yes & Yes & Yes & Yes & 100 \\
\hline Joseph (72) & Yes & Yes & Yes & Yes & Yes & 100 \\
\hline Lidegaard (73) & Yes & Yes & Yes & Yes & Yes & 100 \\
\hline Piana (74) & Yes & Yes & Yes & Yes & Yes & 100 \\
\hline
\end{tabular}


Preprint version

\begin{tabular}{llllll}
\hline Lewis (76) & No & Yes & Yes & Yes & No \\
\hline $\begin{array}{l}\text { Groven (75) } \\
\text { Mixed studies }\end{array}$ & Yes & Yes & Yes & Yes & Yes \\
& $\begin{array}{l}\text { 1. Is there an adequate } \\
\text { rationale for using a mixed } \\
\text { methods design to address the } \\
\text { research question? }\end{array}$ & $\begin{array}{l}\text { 2. Are the different } \\
\text { components of the study } \\
\text { effectively integrated to } \\
\text { answer the research question? }\end{array}$ & $\begin{array}{l}\text { 3. Are the outputs of } \\
\text { the integration of } \\
\text { qualitative and } \\
\text { quantitative } \\
\text { components } \\
\text { adequately } \\
\text { interpreted? }\end{array}$ & $\begin{array}{l}\text { 4. Are divergences and inconsistencies } \\
\text { between quantitative and qualitative } \\
\text { results adequately addressed? }\end{array}$ & $\begin{array}{l}\text { 5. Do the different } \\
\text { components of the study } \\
\text { adhere to the quality criteria } \\
\text { of each tradition of the } \\
\text { methods involved? }\end{array}$ \\
\hline Adachi-Mejia (77) & Yes & Yes & Yes & Yes & No \\
\hline Lattimore (78) & Yes & Yes & Yes & Yes & No \\
\hline Leone (79) & Yes & Yes & Yes & Yes & No \\
\hline
\end{tabular}


Table S2. Data extraction and classification details for physical activity motives

\begin{tabular}{|c|c|c|c|}
\hline References & $\begin{array}{l}\text { Survey items/question OR } \\
\text { Second-order construct: "First-order construct" }\end{array}$ & Average response & Scores \\
\hline \multicolumn{4}{|l|}{ Physical factors } \\
\hline Ashton (54) & Lose weight & $46.4 \%$ reported as key motivator & 3 \\
\hline Skov-Ettrup (63) & Lose weight & & 2 \\
\hline Leone (79) & $\begin{array}{l}\text { Weight management, Weight-loss may be the only benefit which is desirable } \\
\text { enough to motivate obese women to overcome their barriers to exercise; "Losing } \\
\text { weight, seeing the numbers go down on the scale, feeling as though my clothes are } \\
\text { fitting better or I get into, you know my smaller size clothes and that sort of thing } \\
\text { that motivates me to work out, to be more purposeful in doing physical activity" }\end{array}$ & Most common perceived & 3 \\
\hline Guess (70) & $\begin{array}{l}\text { Weight loss as a primary motivation: "Right, and when you're looking at the scale, } \\
\text { each time maybe I go to the gym, you lose I pounds } 2 \text { pounds, so I think afterwards, } \\
\text { I am losing, so I think to myself I need to keep going, it's motivating to me."; "Yes, } \\
\text { always } 3 \text { times a week, after working, losing the weight, it motivates you, makes } \\
\text { you feel you want to do a little bit more",; "I mean, does the person really come to } \\
\text { the doctor and say I want to exercise because I want to be healthy or send me to the } \\
\text { gym because I want to be healthy? No! They go on exercise and diet programs } \\
\text { because they want to lose weight"; "Nothing is stopping me at the moment once I } \\
\text { start to lose a little bit of weight I start to feel motivated", }\end{array}$ & Primary motivation for nearly all women & 3 \\
\hline Danielsen (69) & $\begin{array}{l}\text { Persistence in weight regulation grounded in a fundamental fear of gaining weight. } \\
\text { What they feared the most was to "go back to where I was." }\end{array}$ & & 2 \\
\hline Igelström (71) & $\begin{array}{l}\text { Desire for a change: "I want to lose weight"; "I am fed up with being in this } \\
\text { situation" }\end{array}$ & & 2 \\
\hline Groven $(75)$ & $\begin{array}{l}\text { Weight reduction is seemed by women as essential; "You actually exercise your } \\
\text { entire body. You go through every muscle in your body. I think that is very } \\
\text { important, especially when it comes to burning fat. You have to push your body in } \\
\text { order to burn fat and lose weight. ". }\end{array}$ & & 2 \\
\hline
\end{tabular}




\section{Preprint version}

Lewis (76)

To lose weight to becoming "fit," "healthy," and "athletic" rather than "thin". "Men don't want to be thin. Our goal is to have low body fat, to be muscular. The ideal

body shape for men is quite a muscular one in men's minds."

\begin{tabular}{|c|c|c|c|}
\hline Ashton (54) & Improve fitness, improve muscle mass, improve sporting performance & & 2 \\
\hline Skov-Ettrup (63) & Get or stay fit & & 2 \\
\hline Bowen (67) & $\begin{array}{l}\text { To increase energy: "When you do it [physical activity], you do feel better. I'm not } \\
\text { tired I just feel good"; "I'm not as tired as I used to be. And I just feel good. " }\end{array}$ & One of the most expressed motivational factors. & 3 \\
\hline Danielsen (69) & $\begin{array}{l}\text { "Now I notice that I get a lot more energy from being active. Therefore, if I'm tired, } \\
\text { going to the gym or going for a walk or doing something [physical activity] is } \\
\text { useful for me". } \\
\text { Change in lifestyle and self-perception due to improved physical fitness: "Before I } \\
\text { was a spectator in my own life, now I'm participating." }\end{array}$ & & 2 \\
\hline Joseph (72) & $\begin{array}{l}\text { Increase energy: "Have more energy". "Being able to maybe keep up with family- } \\
\text { with my son and my husband - and being able to do those things and not be } \\
\text { exhausted or not sit out the ride or sit out the trip for whatever reason" }\end{array}$ & & 2 \\
\hline Lidegaard (73) & $\begin{array}{l}\text { Give energy to the rest of everyday life; When you do it [physical activity], you do } \\
\text { feel better. I'm not tired I just feel good". "I'm not as tired as I used to be. And I } \\
\text { just feel good." }\end{array}$ & & 2 \\
\hline Ashton (54) & Improve overall health, to live longer & & 2 \\
\hline Bowen (67) & To decrease pain and stiffness & The most commonly expressed motivational factors & 3 \\
\hline Joseph (72) & $\begin{array}{l}\text { Health outcomes; Reduced risk for chronic disease "Ultimately it's just increased } \\
\text { health. Be healthier, you'll feel better, have more energy. Better response to stress, } \\
\text { all those kinds of things" }\end{array}$ & Mentioned in all focus group & 3 \\
\hline Lidegaard (73) & $\begin{array}{l}\text { To maintain or improve health; Increased motivation if visible improvement in } \\
\text { health parameters; Reviewing/reaching health goals "One of the good things about } \\
\text { diabetes is that you can measure pretty quickly if what you're doing is the right } \\
\text { thing [... I instead of waiting for the rather long-term effect of exercise on my } \\
\text { weight. The immediate responses is really motivating to me. " }\end{array}$ & & 2 \\
\hline
\end{tabular}




\begin{tabular}{|c|c|c|c|}
\hline \multicolumn{4}{|c|}{ Psychological factors } \\
\hline Igelström (71) & $\begin{array}{l}\text { Threat or coercion; Direct advice from a health care provider "If someone told me } \\
\text { you're going to die tomorrow if you don't exercise, then of course I would be more } \\
\text { physically active" }\end{array}$ & Some participants & 1 \\
\hline Joseph (72) & $\begin{array}{l}\text { Reduced risk of chronic conditions; "For me, the motivating factor is I want to live. } \\
\text { You know. Straight up, I want to live... you see people who are passing away at } \\
\text { your age, I guess. And, you know, because of heart attacks or, you know, things, } \\
\text { diabetes or whatever these things" }\end{array}$ & Mentioned in all focus group & 3 \\
\hline Ashton (54) & Improve mental health and well-being, improve sleeping patterns, & & 2 \\
\hline Danielsen (69) & Feeling of vigor and better mood & Important incentive for PA & 3 \\
\hline Lidegaard (73) & Good sense in the body, sense of well being & & 2 \\
\hline Ashton (54) & Improve body image, attract a partner & & 2 \\
\hline Joseph (72) & $\begin{array}{l}\text { To improve physical appearance: "My motivation would be clothes, actually. Yeah, } \\
\text { and not having to buy plus size clothes, and not having to spend ridiculously large } \\
\text { amounts of money for clothing." }\end{array}$ & Mentioned by some women & 1 \\
\hline Ashton (54) & Enjoyment & & 2 \\
\hline Skov-Ettrup (63) & Have fun & & 2 \\
\hline Skov-Ettrup (63) & Unwind & & 2 \\
\hline Lidegaard (73) & An opportunity to reduce stress and recharge & & 2 \\
\hline
\end{tabular}




\section{Preprint version}

\section{Socio-ecological factors}

Living. Independence was a factor that was valued among all the women and a motivator to be physically active because it played a vital role in their health.

\begin{tabular}{|c|c|c|c|}
\hline Joseph (72) & $\begin{array}{l}\text { Being a good role model to others, particularly their family: "I have children. } \\
\text { They're teenagers, and I'm trying to break out of the statistics category regarding } \\
\text { African-American women [referring to cardiometabolic health disparities]". "I } \\
\text { would say setting a good example for my children is another motivating factor." }\end{array}$ & Several women & 1 \\
\hline Asthon (54) & Social influences & & 2 \\
\hline Skov-Ettrup (63) & Socialize & & 2 \\
\hline
\end{tabular}




\section{Preprint version}

Groven (75)

Lewis (76)

Motivated by treatment group: "The others stayed in the program, which made me hang in as well. It sort of motivated me, seeing the other participants pushing

themselves".

Motivated by a physiotherapist: "She (physiotherapist) is direct whether it can hurt us or please us. "She tells us how to do things better. But I think it important that she also tells me that I can do better. I like the way she pushed us,'

They emphasized that exercising together with persons in the same situation as themselves (treatment group for organized for patients with obesity problem) made them feel more recognized and accepted. Sense of belonging. Treatment group provides a common ground in which the women can feel equal, regardless of their body weight.

More motivated to engage in physical activity if it involved family members or friends: "You'd never go and run around the track 4 times a week, but you might if you knew it was a good time and you'd meet other people who were all doing the same."

Danielsen (69)
Challenged by others in a group class to "try things": "It was motivating. Because most of them were "in the same boat" as me, they wanted to exercise and got a "kick" from it. They wanted to exercise more and get involved and engaged, so we motivated and helped each other,..."

Share positive and negative experiences "Here I can meet others with the same problems as myself. For everyone have problems due to their weight, right. And we share the same problems,... We understand each other"

Being in the same boat: "We looked a little similar, everything was in a way very safe"; "It was okay to breathe and wheeze and it was okay to [let the fat] wiggle and all this, you know, when we exercised." 
Table S3. Data extraction and classification details for physical activity barriers

\begin{tabular}{|c|c|c|c|c|}
\hline & References & $\begin{array}{l}\text { Survey items/question OR } \\
\text { Second-order construct: "First-order construct" }\end{array}$ & Average response & Scores \\
\hline Phys & ical factors & & & \\
\hline \multirow{10}{*}{ 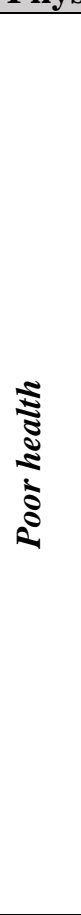 } & Napolitano (60) & Poor health & $1.45 / 5$ for agreement & 1 \\
\hline & Rimmer (61) & Health concerns prevent me from exercising & $39 \%$ agreed & 2 \\
\hline & \multirow[t]{2}{*}{ Adachi-Mejia (77) } & Lack of general good health & As weight $\lambda$, this item $\lambda$ in frequency & \multirow[t]{2}{*}{2} \\
\hline & & $\begin{array}{l}\text { Arthritis; Hip issues; Chronic illness; Foot issues; Knee issues; Health issues; } \\
\text { Ankle injury; Asthma; Back issues; Migraines; Diabetes; Smocking. }\end{array}$ & $\begin{array}{l}\text { Knee issues were described as a barrier in all weight } \\
\text { classes. Asthma was mentioned as barriers in all } \\
\text { obese classes. Participants described more types of } \\
\text { physical barriers as weight class increased }\end{array}$ & \\
\hline & Coe (68) & $\begin{array}{l}\text { Health concerns } \\
\text { Physical limitations }\end{array}$ & $\begin{array}{l}\text { Mentioned by all members } \\
\text { Mentioned by all male participants }\end{array}$ & \multirow{2}{*}{$\frac{3}{2}$} \\
\hline & Guess (70) & $\begin{array}{l}\text { "(Physical activity) is not really for someone like me with my health conditions". } \\
\text { "I feel comfortable, the problem is as soon as I feel I have problem with my } \\
\text { asthma" }\end{array}$ & & \\
\hline & Igelström (71) & Medical problems & & 2 \\
\hline & Lattimore (78) & $\begin{array}{l}\text { Health: "Arthritis, fibromyalgia, muscular, degeneration, heart conditions, and } \\
\text { surgeries" }\end{array}$ & $32.3 \%$ & 2 \\
\hline & Leone (79) & $\begin{array}{l}\text { Chronic condition: "I can't do it anymore, because I can't walk like that anymore } \\
\text { "cause my blood pressure spikes" } \\
\text { Injury or surgery }\end{array}$ & Second most common barrier to exercise. & 3 \\
\hline & Lidegaard (73) & $\begin{array}{l}\text { Poor physical conditions: "I can't ride a bicycle and walk as I used to because of } \\
\text { problems with my legs, right?" }\end{array}$ & Substantial barrier & 3 \\
\hline \multirow{6}{*}{ 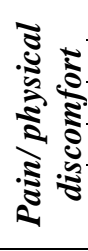 } & Labrunee (59) & Pain following PA & very frequent $(>60 \%)$ & 3 \\
\hline & Napolitano (60) & Minor aches and pain & $2.13 / 5$ for agreement & 2 \\
\hline & Egan (56). & Physical discomfort & $23.4 \%$ reported as a major barrier (\# 1 barrier) & 3 \\
\hline & Rimmer (61) & Pain prevents me from exercising & $64 \%$ agreed & 3 \\
\hline & \multirow[t]{2}{*}{ Stankevitz (64) } & Pain or discomfort & $2.7 / 5$ for frequency & \multirow[t]{2}{*}{1,5} \\
\hline & & Feeling nauseated & $1.5 / 5$ for frequency & \\
\hline
\end{tabular}




\begin{tabular}{|c|c|c|c|c|}
\hline & Adachi-Mejia (77) & Pain & Mentioned as barrier in all obese classes (I, II and III) & 2 \\
\hline & Bowen (67) & $\begin{array}{l}\text { Chronic pain: "My legs hurt when I walk and [with] standing; when I stand too } \\
\text { long, it's my back" "I don't participate in the exercise. I used to but my back } \\
\text { bother me now... So I don't exercise. I can't go through that exercise [at the gym]" }\end{array}$ & $\begin{array}{l}\text { Mentioned by many participants and as a significant } \\
\text { barrier. }\end{array}$ & 3 \\
\hline & Leone (79) & Physically uncomfortable while exercising & & 2 \\
\hline & Danielsen (69) & Exercise is painful; Pain related to limited mobility: "I've never had so much pain" & Experienced by all participants. & 3 \\
\hline & Igelström (71) & $\begin{array}{l}\text { Pain as a side effect of physical activity; Bodily sensations: "Unpleasant sensations } \\
\text { from the heart while exercising" }\end{array}$ & & 2 \\
\hline & Lidegaard (73) & $\begin{array}{l}\text { Pain: "I'm pretty sure I do get the exercise, but I should do more of it. But when I } \\
\text { do more of it, well then it's hard on my knees and back." }\end{array}$ & $50 \%$ & 3 \\
\hline & Piana (74) & "Muscle pain" "injuries, accidents" & & 2 \\
\hline & Groven (75) & Pain: "Pain in my knees, in my back, in my groin. I really felt like a failure." & Many & 2 \\
\hline & Napolitano (60) & I am too overweight & $2.74 / 5$ for agreement & 2 \\
\hline & Leone (79) & My current weight makes it difficult for me to exercise & $46.5 \%$ agreed & 2,5 \\
\hline & & $\begin{array}{l}\text { Weight: “...the weight goes down and then I feel better about exercising, because } \\
\text { who wants to be, you know, big, fat, tight clothes, that kind of thing, getting out of } \\
\text { breather earlier or something like that, although my breath really is pretty good." }\end{array}$ & Weight-related barrier was the first common theme & \\
\hline .5 & Lattimore (78) & Being overweight (both currently and for life) & & 2 \\
\hline & Danielsen (69) & Living a heavy body: "I couldn't do anything " & & 2 \\
\hline & Guess (70) & Weight & Majority of participants & 3 \\
\hline & Adachi-Mejia (77) & Weight & Mentioned as barriers in all obese classes. & 2 \\
\hline & Piana (74) & $\begin{array}{l}\text { Weight: "Difficulty of movement caused by obesity" "Difficulty in tying my shoe- } \\
\text { laces and/or standing up" }\end{array}$ & & 2 \\
\hline & Napolitano (60) & Lack of energy & $3.47 / 5$ for agreement & 3 \\
\hline b & & I am usually too tired to exercise & $3.11 / 5$ for agreement & \\
\hline$\frac{\pi}{3}$ & Rimmer (61) & Lack of energy & $36 \%$ agreed & 2 \\
\hline$\Xi 2$ & Egan (56) & Too tired to exercise & $15.9 \%$ reported as a major barrier & 2 \\
\hline 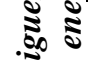 & Genkinger (57) & Too fatigued by exercise & $13 \%$ strongly agreed or agreed & 1,5 \\
\hline$\sqrt[3]{3}$ & & Too tired & $37 \%$ strongly agreed or agreed & \\
\hline & Stankevitz (64) & Fatigue (lack of energy) & $3.3 / 5$ for frequency & 3 \\
\hline & Leone (79) & I don't have the energy to exercise & $57,8 \%$ agreed & 3 \\
\hline
\end{tabular}




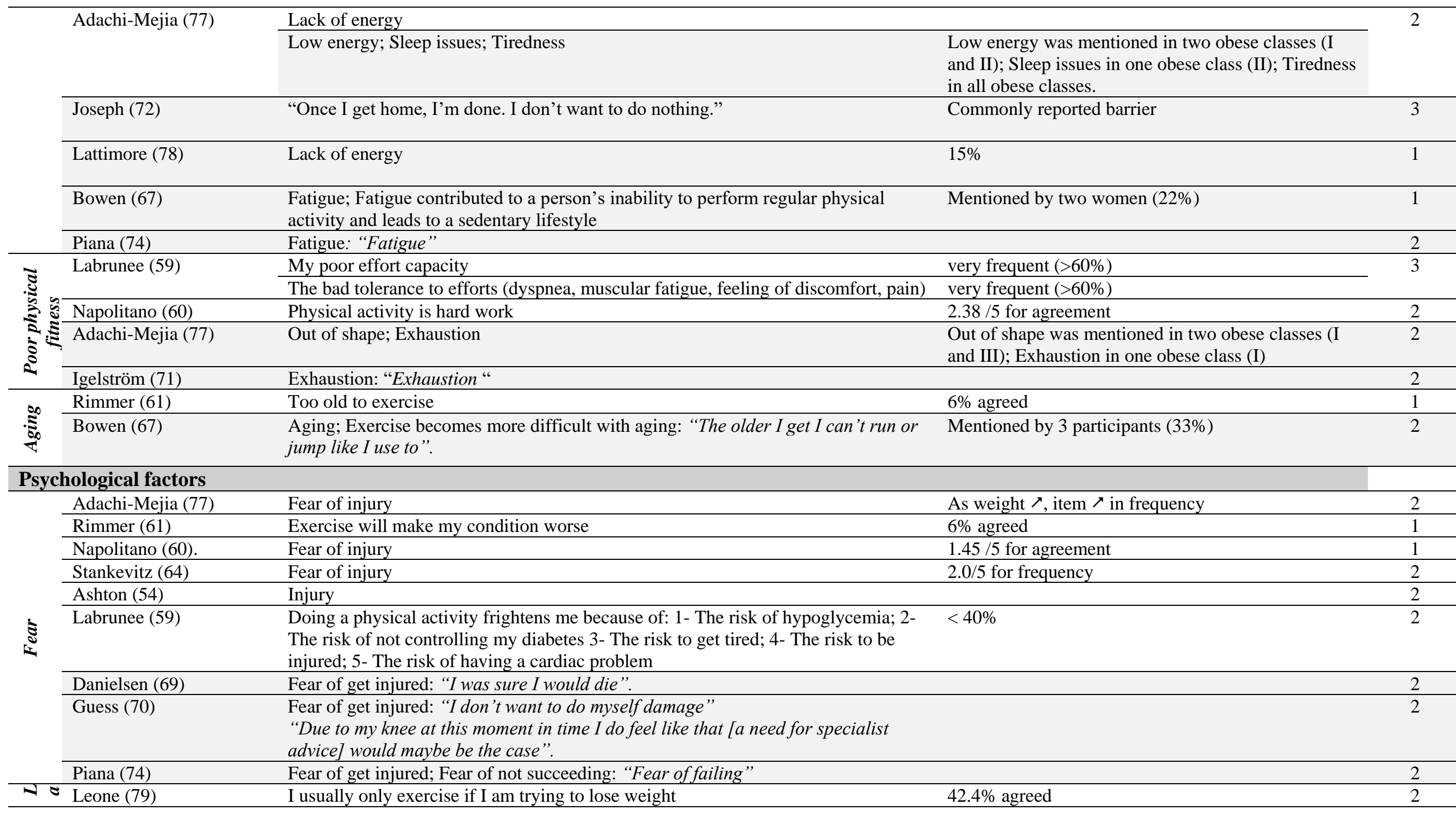




\begin{tabular}{|c|c|c|c|c|}
\hline & \multirow{2}{*}{ Stankevitz (64) } & Lack of self-discipline & $3.5 / 5$ for frequency & \multirow[t]{2}{*}{3} \\
\hline & & Procrastination & $3.3 / 5$ for frequency & \\
\hline & Ashton (54) & Lack of motivation & & 2 \\
\hline & Labrunee (59) & Low motivation & very frequent $(>60 \%)$ & 3 \\
\hline & Napolitano (60) & Lack of self-discipline or willpower & $4.27 / 5$ for agreement & 3 \\
\hline & Rye (62) & Lack of willpower & $54.5 \%$ agreed & 3 \\
\hline & James (58) & I don't have the willpower to exercise & $\begin{array}{l}\text { Obese class } 1 \text { and } 2 \text { reported stronger levels of } \\
\text { agreement with this barrier than other weight group }\end{array}$ & 2 \\
\hline & Genkinger (57) & Lack of motivation & $63 \%$ strongly agreed or agreed & 3 \\
\hline & Rimmer (61) & Lack of motivation & $30 \%$ agreed & 2 \\
\hline & \multirow[t]{2}{*}{ Adachi-Mejia (77) } & Self-discipline & $\begin{array}{l}\text { Most frequently mentioned barrier among people } \\
\text { with obesity }\end{array}$ & \multirow[t]{2}{*}{2,5} \\
\hline & & Lack of motivation; In a rut; Don't see results & $\begin{array}{l}\text { Lack of motivation was mentioned for four out of } \\
\text { five weight classes; In a rut in one obese class (II); } \\
\text { Don`t see results in one obese class (III) }\end{array}$ & \\
\hline & Piana (74) & $\begin{array}{l}\text { Lack of motivation, Too many excuses; Lack of personal incentives } \\
\text { : "Not a chieving the target" "Why am I trying?" "Excuses for not doing it" "It is } \\
\text { hard to get going" }\end{array}$ & & 2 \\
\hline & Lattimore (78) & Lack of motivation; motivation & $28.3 \%$ and $41,6 \%$ & 2 \\
\hline & Lidegaard (73) & $\begin{array}{l}\text { Broken exercise routine and difficulty to start exercising again: "I just didn't do it } \\
\text { as a daily routine [...] It took several months to get it running again as a routine." }\end{array}$ & Minor topic & 1 \\
\hline & Joseph (72) & $\begin{array}{l}\text { Don't see results: "Sometimes all the goals make you feel like the little bit you do } \\
\text { isn't worth it." }\end{array}$ & & 2 \\
\hline \multirow{12}{*}{ 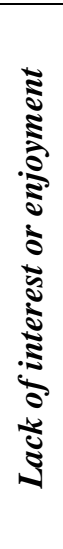 } & Genkinger (57) & Exercise is boring & $18 \%$ strongly agreed or agreed & 1 \\
\hline & \multirow[t]{2}{*}{ Egan (56) } & Exercise is too boring & $20.7 \%$ reported as a major barrier (\# 2 barrier) & \multirow[t]{2}{*}{2} \\
\hline & & Dislike of gym & $9.7 \%$ reported as a major barrier & \\
\hline & \multirow[t]{3}{*}{ Napolitano (60) } & PA is too boring & $2.26 / 5$ for agreement & \multirow[t]{3}{*}{2,3} \\
\hline & & Lack of interest in PA & $3.13 / 5$ for agreement & \\
\hline & & I do not enjoy PA & $2.66 / 5$ for agreement & \\
\hline & \multirow{3}{*}{ Rimmer (61) } & PA is boring or monotonous & $24 \%$ agreed & \multirow{3}{*}{1} \\
\hline & & Satisfied with physical appearance & $12 \%$ agreed & \\
\hline & & Exercise is too difficult & $18 \%$ agreed & \\
\hline & \multirow[t]{3}{*}{$\begin{array}{l}\text { Stankevitz (64) } \\
\text { (6) }\end{array}$} & Exercise is not in routine & $3.2 / 5$ for frequency & \multirow[t]{3}{*}{2,4} \\
\hline & & Lack of interest in exercise & $2.9 / 5$ for frequency & \\
\hline & & Lack of enjoyment from exercise & $2.7 / 5$ for frequency & \\
\hline
\end{tabular}




\begin{tabular}{|c|c|c|c|c|}
\hline & & Exercise was boring & $2.5 / 5$ for frequency & \\
\hline & & Exercise is not a priority & $3.0 / 5$ for frequency & \\
\hline & Rye (62) & Don't need more & $4.6 \%$ agreed & 1 \\
\hline & Labrunee (59) & The lack of desire & very frequent $(>60 \%)$ & 3 \\
\hline & Adachi-Mejia (77) & $\begin{array}{l}\text { Prefer to do other things; Not fun; Dislike exercise; Not thinking about doing } \\
\text { exercise; Sedentary activities }\end{array}$ & $\begin{array}{l}\text { Prefer to do other things was mentioned in one obese } \\
\text { class (I); Not fun in one obese class (I); Dislike was } \\
\text { mentioned in one obese class (II); Not thinking about } \\
\text { doing exercise in one obese class (I); Sedentary } \\
\text { activities in one obese class (III). }\end{array}$ & 2 \\
\hline & Lattimore (78) & Lack of interest & $5.7 \%$ & 1 \\
\hline & Piana (74) & $\begin{array}{l}\text { Resistance to practice unpleasant activities: "I hate running, and doing physical } \\
\text { activity is unpleasant". }\end{array}$ & & 2 \\
\hline & Egan (56) & Too depressed to exercise & $5.5 \%$ reported as a major barrier & 1 \\
\hline 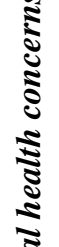 & Adachi-Mejia (77) & Stress; Depression; Mood; Lazy; Procrastination; Impatience; Sadness & $\begin{array}{l}\text { Depression was mentioned as a barrier in all three } \\
\text { obese classes. Stress and mood were mentioned in } \\
\text { one obese class (I). Lazy was mentioned in two obese } \\
\text { classes (II, III), Procrastination was mentioned in one } \\
\text { obese class (II). Impatience was mentioned was } \\
\text { mentioned in one obese class (III) }\end{array}$ & 2 \\
\hline$\sqrt[2]{2}$ & Bowen (67) & Laziness & Mentioned by 2 participants ( $22 \%)$ & 1 \\
\hline$\Sigma$ & Igelström (71) & Psychological distress & Some participants & 1 \\
\hline & Egan (56) & Negative past experience of exercise & $4.1 \%$ reported as a major barrier & 1 \\
\hline & Napolitano (60) & I hate to fail so I do not try & $2.13 / 5$ for agreement & 2 \\
\hline & Igelström (71) & Negative past experience of exercise & Some participants & 1 \\
\hline 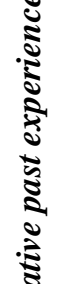 & Joseph (72) & $\begin{array}{l}\text { Being forced to perform activities they did not want to perform; Being } \\
\text { uncomfortable with PA due to early onset of physical development; Embarrassment } \\
\text { and teasing from other children; Hiring a personal trainer and/or engaging in } \\
\text { structured exercise classes that were too intense or beyond their skill level. } \\
\text { "My personal trainer was negative in his approach" "I signed up for a free class. } \\
\text { It was a Cross-Fit class (....) the next day I felt like I was hit by a truck, and I didn't } \\
\text { go back." }\end{array}$ & A few women & 1 \\
\hline$z^{\infty}$ & Lattimore (78) & $\begin{array}{l}\text { Negative exercise perceptions or } \\
\text { Experience }\end{array}$ & $4 \%$ & 1 \\
\hline
\end{tabular}




\begin{tabular}{|c|c|c|c|c|}
\hline \multirow{10}{*}{ 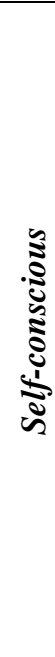 } & Egan (56) & Embarrassed about physical appearance & $4.1 \%$ reported as a major barrier & 1 \\
\hline & Napolitano (60) & Self-conscious about my look when I do activities & $2.6 / 5$ for agreement & 2 \\
\hline & Labrunee (59) & Doing a physical activity frightens me because of: 6 - The others' look & $<40 \%$ & 2 \\
\hline & James (58) & $\begin{array}{l}\text { I am uncomfortable with how I look while exercising or while wearing exercise } \\
\text { clothing }\end{array}$ & $\begin{array}{l}\text { Obese class } 1 \text { and } 2 \text { reported stronger levels of } \\
\text { agreement with this barrier than other weight groups }\end{array}$ & 2 \\
\hline & Rimmer (61) & Feel uncomfortable exercising in a fitness center & $30 \%$ agreed & 2 \\
\hline & Ashton (54) & Intimidation/embarrassment & & 2 \\
\hline & \multirow[t]{2}{*}{ Leone (79) } & $\begin{array}{l}\text { I am uncomfortable with how I look while exercising or while wearing exercise } \\
\text { clothing }\end{array}$ & $44.4 \%$ agreed & \multirow[t]{2}{*}{1,5} \\
\hline & & $\begin{array}{l}\text { Uncomfortable with appearance while exercising: "I want to exercise by myself, but } \\
\text { the only reason I don't want to join a club, or anything like that is because } \\
\text { everybody in there is like a size 2" }\end{array}$ & $15,8 \%$ & \\
\hline & Guess (70) & "I am too self-conscious to go to the gym with all these skinny little women". & & 2 \\
\hline & Danielsen (69) & $\begin{array}{l}\text { Not fitting in to typical exercise contexts: "As when you enter Elixia [national } \\
\text { fitness center] with } 140 \mathrm{~kg} \text { and the others are highly trained people, then you feel a } \\
\text { bit like that, you know what I mean?" "Feeling of bodily "otherness." }\end{array}$ & Some participants. & 1 \\
\hline \multirow{8}{*}{ 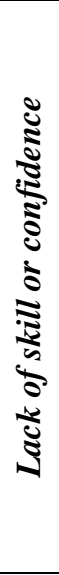 } & Napolitano (60) & Lack of skill & $2.14 / 5$ for agreement & 2 \\
\hline & Ashton (54) & Lack of skills/knowledge & & 2 \\
\hline & Stankevitz (64) & Lack of skill & $2.2 / 5$ for frequency & 2 \\
\hline & Adachi-Mejia (77) & $\begin{array}{l}\text { Lacking coordination } \\
\text { Self-perception as non-physical }\end{array}$ & $\begin{array}{l}\text { Lacking coordination and self-perception as non- } \\
\text { physical were mentioned as barrier in one obese class } \\
\text { (II) }\end{array}$ & 2 \\
\hline & Danielsen (69) & Feeling of not being able to do anything: "I couldn't do anything." & Prominent theme & 3 \\
\hline & Guess (70) & $\begin{array}{l}\text { Lack of confidence related to ability and perceived ability. "I wouldn't feel } \\
\text { comfortable doing it you know in a public place you know, obviously you have } \\
\text { limitations." }\end{array}$ & Many participants & 3 \\
\hline & Igelström (71) & Doubt if they will be able to obtain the benefits & Some participants & 1 \\
\hline & Joseph (72) & $\begin{array}{l}\text { Participants reported their own self as a primary source of discouragement: "I don't } \\
\text { necessarily have anyone who's not supportive, but I know I can be my own worst } \\
\text { critic." }\end{array}$ & & 2 \\
\hline \multirow{4}{*}{ 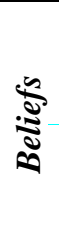 } & Rimmer (61) & Exercise will not improve my condition & $9 \%$ agreed & 1 \\
\hline & Ashton (54) & Exercising is not a masculine/bloke thing to do & & 2 \\
\hline & Guess (70) & $\begin{array}{l}\text { Resistance exercises as a masculine activity; "I don `t want build muscles. To me } \\
\text { it's like a man's sport." }\end{array}$ & Amongst all the participants & 3 \\
\hline & Joseph (72) & $\begin{array}{l}\text { Participants belief that the racial history contributes to health benefits related to PA: } \\
\text { "It's [referring the PA for health benefits] really tailored to the individual because }\end{array}$ & Few participants & 1 \\
\hline
\end{tabular}


there's, 'What's your racial history?' And not just what you might think you see,

but what's your history because that can contribute to your health benefits."

Leone (79) Only women who are trying to lose weight need to exercise: "I have never had to exercise in my young life to stay in shape."

"I think weight gain does drive exercise. If I could weigh 110 pounds and never

exercise, I'd be very happy."

Lewis (76) Being too concern about health is not masculine

\begin{tabular}{|c|c|c|c|c|}
\hline \multicolumn{5}{|c|}{ Socio-ecological factors } \\
\hline \multirow{17}{*}{ 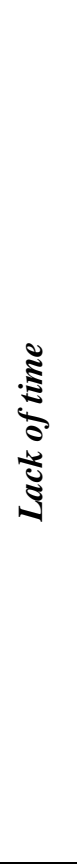 } & Napolitano (60) & Lack of time & $3.43 / 5$ for agreement & 3 \\
\hline & Rye (62) & Lack of time & $25.7 \%$ agreed & 2 \\
\hline & Rimmer (61) & Lack of time & $15 \%$ agreed & 1 \\
\hline & Egan (56) & No time to exercise & $20 \%$ reported as a major barrier (\# 3 barrier) & 3 \\
\hline & Ashton (54) & Lack of time to exercise because of busy lifetime & & 2 \\
\hline & \multirow[t]{3}{*}{ Genkinger (57) } & No time to exercise & $50 \%$ strongly agreed or agreed & \multirow[t]{3}{*}{2,3} \\
\hline & & Time Inconvenient & $28 \%$ strongly agreed or agreed & \\
\hline & & Too busy to exercise & $47 \%$ strongly agreed or agreed & \\
\hline & \multirow[t]{2}{*}{ 799- Masterson et al. } & Hard to make time & $39 \%$ agreed & \multirow[t]{2}{*}{2,5} \\
\hline & & Cannot make time & $81.6 \%$ agreed & \\
\hline & \multirow[t]{2}{*}{ Stankevitz (64) } & Inconvenient exercise schedule & $3.1 / 5$ for frequency & \multirow[t]{2}{*}{3} \\
\hline & & Lack of time & $3.4 / 5$ for frequency & \\
\hline & \multirow[t]{2}{*}{ Adachi-Mejia (77) } & Lack of time & & \multirow[t]{2}{*}{2} \\
\hline & & Lacking time; Schedule & $\begin{array}{l}\text { Lacking time was mentioned as barrier in all weight } \\
\text { classes; Schedule in one obese class (I). }\end{array}$ & \\
\hline & Lattimore (78) & General lack of time. time & $13.3 \%$ and $30,6 \%$ & 1,5 \\
\hline & Danielsen (69) & $\begin{array}{l}\text { Conflict with other activities and social events; Exercise as time-consuming. "You } \\
\text { have to give up other things in order to exercise." }\end{array}$ & & 2 \\
\hline & Igelström (71) & $\begin{array}{l}\text { Running out of time: "I already have too much to do and adding physical activity } \\
\text { will only stress me further." }\end{array}$ & & 2 \\
\hline \multirow{5}{*}{ 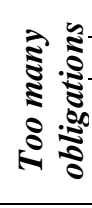 } & Genkinger (57) & Too many family obligations & $29 \%$ strongly agreed or agreed & 2 \\
\hline & Stankevitz (64) & Family responsibilities & $3.3 / 5$ for frequency & 3 \\
\hline & \multirow[t]{3}{*}{ Napolitano (60) } & Family demands & $2.77 / 5$ for agreement & \multirow[t]{3}{*}{2} \\
\hline & & Social demands & $2.26 / 5$ for agreement & \\
\hline & & Work demands & $2.70 / 5$ for agreement & \\
\hline
\end{tabular}




\begin{tabular}{|c|c|c|c|c|}
\hline & Rimmer (61) & Job responsibilities prevent me from exercising & $3 \%$ agreed & 1 \\
\hline & & Family responsibilities prevent me from exercising & $21 \%$ agreed & \\
\hline & Adachi-Mejia (77) & $\begin{array}{l}\text { Obligations; Caregiving duties; Family demands; Home life; Work; Sedentary desk } \\
\text { jobs }\end{array}$ & $\begin{array}{l}\text { Caregiving duties and family in one obese classe (I); } \\
\text { Home life in two obese classes (I and II); Work in all } \\
\text { five of the weight classes; Sedentary desk jobs in one } \\
\text { obese class (II). }\end{array}$ & 2 \\
\hline & Lewis (76) & Long working hours; Desk jobs & Extreme barriers to physical activity & 2.75 \\
\hline & & $\begin{array}{l}\text { Work demands; Family commitments "(...) when I got married I basically stopped } \\
\text { being active to spend more time with the missus". }\end{array}$ & $\begin{array}{l}(\mathrm{n}=20,56 \%) \\
(\mathrm{n}=11,31 \%)\end{array}$ & \\
\hline & Lattimore (78) & Work and family constraints & 7.5 and $15 \%$ & 1 \\
\hline & Lidegaard (73) & $\begin{array}{l}\text { Other priorities and interests: "I just don't have time for it. Well, when I get home, I } \\
\text { just get sucked into family life."; "I always have so many things to do at home that } \\
\text { are a thousand times more important than getting out and exercising." }\end{array}$ & All participants & 3 \\
\hline & Rye (62) & Lack of support & $52.6 \%$ agreed & 3 \\
\hline & Ashton (54) & Social influences (e.g., because your partner, family, or friends are NOT active) & & 2 \\
\hline & Egan (56) & Nobody to exercise with & $3.4 \%$ reported as a major barrier & 1 \\
\hline & & Lack of support from friends and family & $0.7 \%$ reported as a major barrier & \\
\hline & Napolitano (60) & I do not have anyone to do physical activities with me & $2.97 / 5$ for agreement & 2 \\
\hline בे & Stankevitz (64) & Lack of company & $2.7 / 5$ for frequency & 2 \\
\hline$\overline{2}$ & Leone (79) & I don't have any one to exercise with & $48.5 \%$ agreed & 2 \\
\hline$\tilde{z}^{2}$ & Rimmer (61) & Lack of friends/family support & $6 \%$ agreed & 1 \\
\hline $\overrightarrow{8}$ & Adachi-Mejia (77) & Lack of compagny & & 2 \\
\hline $\int_{0}^{\infty}$ & & Being alone; No one to exercise with & $\begin{array}{l}\text { Being alone was mentioned in two obese classes (II } \\
\text { and III); No one to exercise in one obese class (I). }\end{array}$ & \\
\hline$\sqrt[3]{3}$ & Igelström (71) & Lack of family and friends support; Lack of health care services support & Majority & 3 \\
\hline & Coe $(68)$ & $\begin{array}{l}\text { Lack of interpersonal support; Lack of community support; Feeling isolated and } \\
\text { misunderstood. }\end{array}$ & Several male and female participants. & 1 \\
\hline & Piana (74) & "Loneliness" & & 2 \\
\hline & Lattimore (78) & Lack of an exercise partner; Lack of social support; Lack of accountability person & $0.6,1.2$ and $0.6 \%$ & 1 \\
\hline & 799- Masterson et al. & Cost & $50.4 \%$ agreed & 3 \\
\hline & Rimmer (61) & Cost of program & $67 \%$ & 3 \\
\hline$s^{2}$ & Stankevitz (64) & Cost of exercising & $2.8 / 5$ for frequency & 2 \\
\hline & Napolitano (60) & Lack of money & $1.85 / 5$ for agreement & 1 \\
\hline & Rye (62) & Lack of money & $37 \%$ agreed & 2 \\
\hline
\end{tabular}




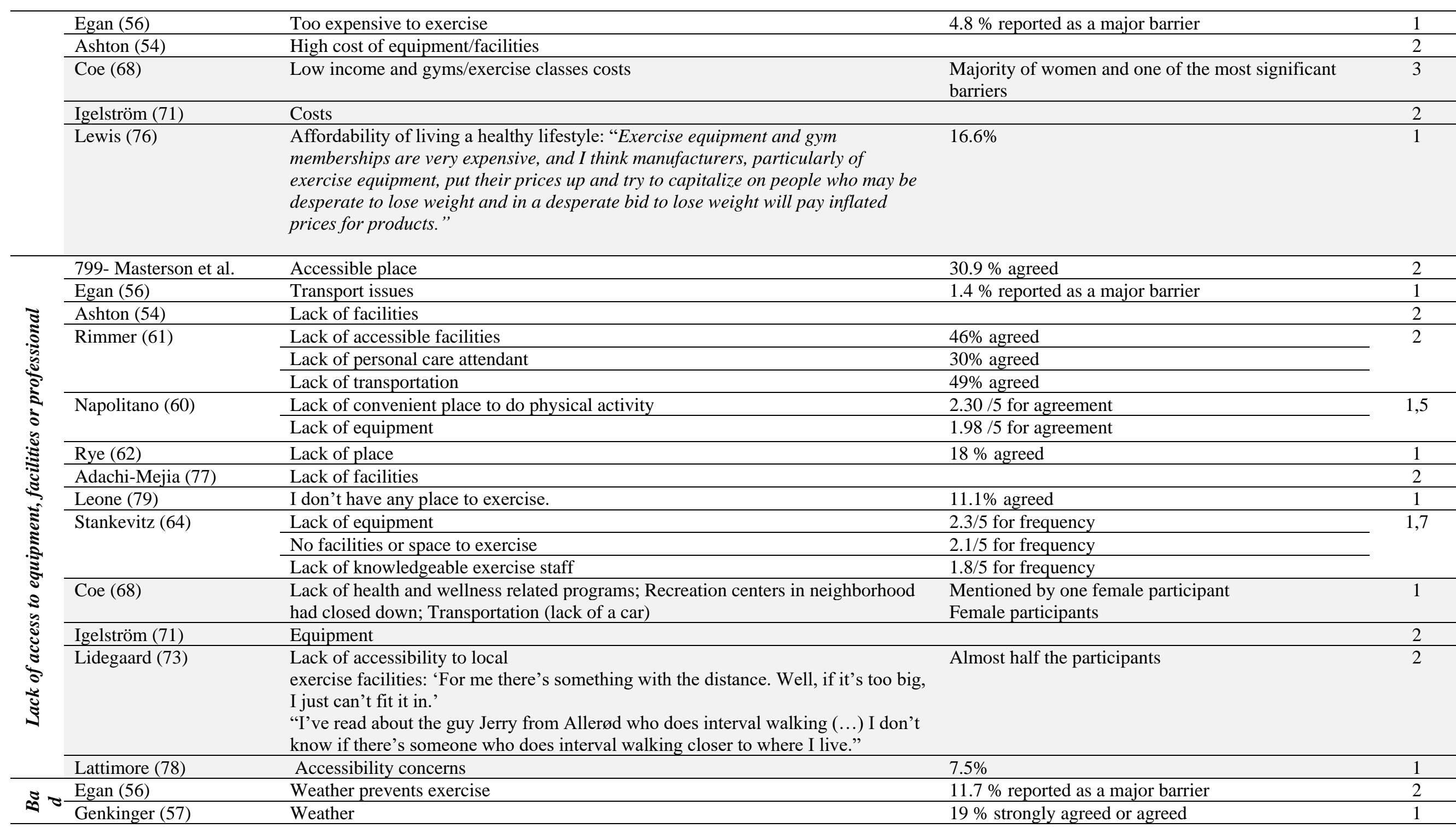




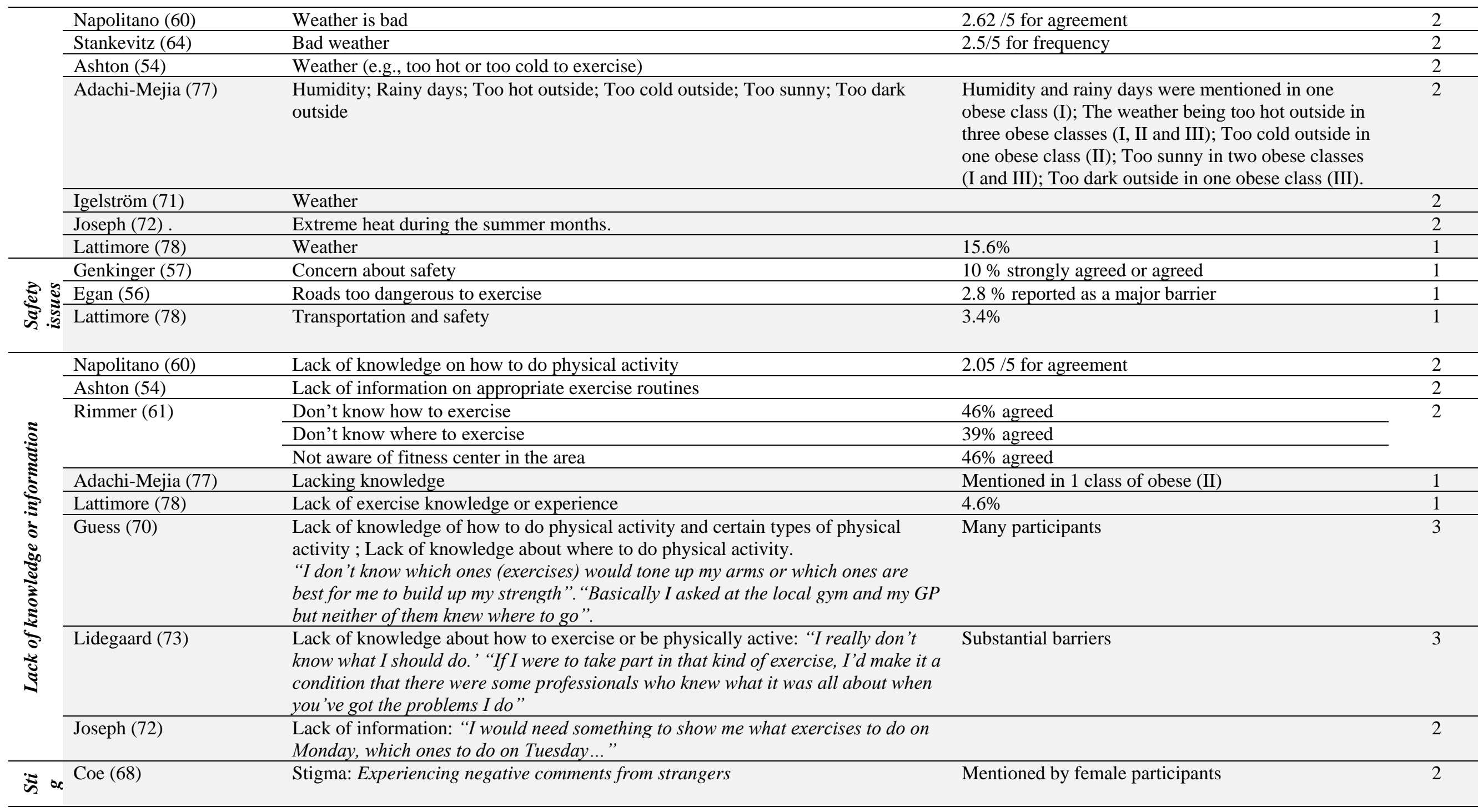


Preprint version

Piana (74) Negative experiences: "During the secondary school I never did sports because was ashamed of my body" "At school they called me "fatty" and let me off the

Markedly negative influence on the patients' attitude 2 activity. I felt excluded, discriminated against."

Groven (75) The gaze of others: "Sometimes I felt sick before going to the fitness training. I towards it. couldn't stand the idea of been stared at." (gym)

"It made me feel disgusting. They looked at me because I was fat.. What is she doing her with a body like that kind of look. It made me feel like an idiot."

Lewis (76) Weight-based stigma: "Doing any physical activity, it's not something to look forward to, it's putting myself out there to be ridiculed again".

"Just walking into a gymnasium is hugely embarrassing. You may as well walk in there naked because everyone turns to you and looks at you and you can just about

hear them going 'oh yuc", 